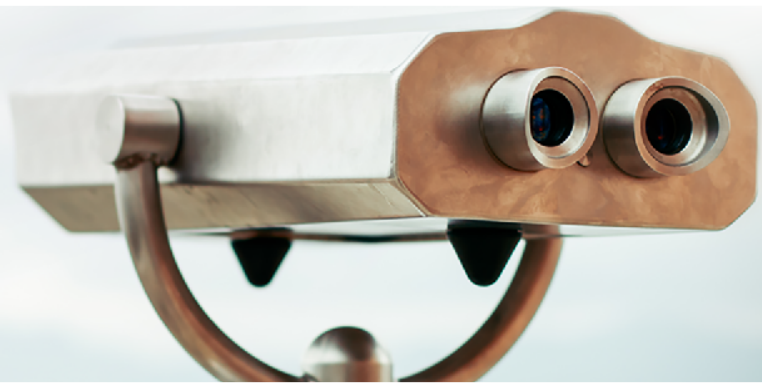

June 22, 2021

Current Policy Perspectives

\title{
Racial Differences in Mortgage Refinancing, Distress, and Housing Wealth Accumulation during COVID-19
}

\author{
Kristopher Gerardi, Lauren Lambie-Hanson, and Paul Willen
}

\begin{abstract}
The COVID-19 pandemic exacerbated racial disparities in U.S. mortgage markets. Black, Hispanic, and Asian borrowers were significantly more likely than white borrowers to miss payments due to financial distress, and significantly less likely to refinance to take advantage of the large decline in interest rates spurred by the Federal Reserve's large-scale mortgage-backed security (MBS) purchase program. The wide-scale forbearance program, introduced by the 2020 Coronavirus Aid, Relief, and Economic Security (CARES) Act, provided approximately equal payment relief to all distressed borrowers, as forbearance rates conditional on nonpayment status were roughly equal across racial/ethnic groups. However, Black and Hispanic borrowers were significantly less likely to exit forbearance and resume making payments relative to their Asian and white counterparts. Persistent differences in the ability to catch up on missed payments could worsen the already large disparity in home ownership rates across racial and ethnic groups. While the pandemic caused widespread distress in mortgage markets, strong house price appreciation in recent years, particularly in 2020, means that foreclosure risk is lower for past-due borrowers now as compared with the aftermath of the Global Financial Crisis and Great Recession. Furthermore, borrowers who have missed payments have significantly higher credit scores now than those who were distressed in the 2007-2010 period, largely due to the widespread availability of forbearance for federally backed mortgages.
\end{abstract}

Kristopher Gerardi (kris.gerardi@atl.frb.org) is a financial economist and senior adviser in the Federal Reserve Bank of Atlanta Research Department. Lauren Lambie-Hanson (Lauren.Lambie-Hanson@phil.frb.org) is an advisor and research fellow in the Consumer Finance Institute at the Federal Reserve Bank of Philadelphia. Paul Willen (Paul.Willen@bos.frb.org) is a senior economist and policy advisor in the Federal Reserve Bank of Boston Research Department.

The views expressed herein are those of the authors and do not indicate concurrence by the Federal Reserve Banks of Atlanta, Philadelphia, or Boston; the principals of the Board of Governors; or the Federal Reserve System.

The authors thank Toni Braun, Julia Cheney, Jessica Dill, Bob Hunt, Mark Jensen, Federico Mandelman, Daniel Sexton, Sarah Stein, Larry Wall, and Jon Willis for helpful comments and Larry Bean, whose suggestions greatly improved the exposition of their ideas. They also thank Daniel Sexton for excellent research assistance and Dan Moulton for help executing their data match. 


\section{Summary of Findings}

The year 2020 saw the emergence of COVID-19 and the worst public health crisis in a century. In the mortgage market, it was a time of extraordinary stress and a time of unprecedented opportunity. Widespread job loss due to the pandemic resulted in waves of missed payments, with the share of mortgages past due approaching levels not seen since the Global Financial Crisis (GFC) and subsequent Great Recession more than a decade ago. At the same time, mortgage rates fell to record lows, with the Freddie Mac Primary Mortgage Market Survey (PMMS) 30-year fixed rate falling below 3 percent for the first time since the initiation of the survey in 1970. The decline in rates spurred a boom in refinances as borrowers rushed to lock in the low rates and lower their monthly payments. In this paper we study how these effects were distributed across the population.

A priori, there are good reasons to think that not all borrowers shared in either the opportunities or the stress in the mortgage market because the COVID-19 pandemic did not affect all sub-groups of the U.S. population equally or in the same way. Initially, the pandemic was concentrated in the Northeast, but later the locus of the disease shifted to the South and West. Some states lifted lockdowns in May of 2020, while other states only began lifting restrictions in May of 2021. Households employed in the leisure and hospitality sectors suffered significant job losses and income declines, whereas households employed in sectors such as information technology and package delivery experienced increases in demand for their services. Low-income households with less than a college degree and little accumulated wealth were hit especially hard, while savings cushioned income disruptions for wealthier households. In addition, there is significant heterogeneity in the population in the incidence of home ownership and mortgage borrowing.

Our analysis focuses on one particular aspect of the heterogeneity of mortgage outcomes during the pandemic: differences across racial and ethnic groups. We do this for two reasons. First, the COVID-19 virus disproportionately impacted minority communities both as a disease and as a disruptive economic force. Black and Hispanic individuals have been at elevated risks of infection, hospitalization, and death. ${ }^{1}$ In addition, minorities experienced significantly worse labor market outcomes during the pandemic. For example, the unemployment rate peaked in April 2020 at 16.7 percent for Black workers versus 14.1 percent for white workers, but even more concerning, unemployment fell far more quickly for white workers as the economy healed. ${ }^{2}$ By September 2020, the white unemployment rate had

\footnotetext{
${ }^{1}$ See Van Dorn, Cooney, and Sabin (2020) as well as CDC data on hospitalizations and death rates by race and ethnicity: www.cdc.gov/coronavirus/2019-ncov/covid-data/investigations-discovery/ hospitalization-death-by-race-ethnicity.html

${ }^{2}$ For simplicity, we use "white" and "Hispanic" to refer to "non-Hispanic white" and "Hispanic white,"
} 
fallen by more than half to 7.0 percent, whereas in March 2021, almost a year after the pandemic started, the Black unemployment rate was still close to 10 percent. $^{3}$

The second reason to focus on racial differences in mortgage outcomes is that recent work by Gerardi, Willen, and Zhang (2020) documents significant differences in refinance behavior across racial and ethnic groups. They find that disparities were especially large during periods of expansionary, unconventional monetary policy, such as the quantitative easing (QE) programs adopted by the Federal Reserve to combat the GFC. Since the Fed implemented a large-scale mortgage-backed security (MBS) purchase program in response to the pandemic, there is concern that similar disparities emerged. ${ }^{4}$

In the refinancing space, we document large differences across racial and ethnic groups. We estimate that through October 2020, only 6 percent of Black borrowers refinanced as compared with almost 12 percent of white borrowers, 14 percent of Asian borrowers, and 9 percent of Hispanic borrowers. An alternative way to measure inequality in refinances is to look at the payment savings. We estimate that the typical refinance reduced the borrower's monthly payment by $\$ 279$, leading to a payment reduction of $\$ 5.3$ billion per year for all households that refinanced. Of those savings, we estimate that only $\$ 198$ million, or 3.7 percent, went to Black households. To put these numbers in perspective, Black households account for 13.3 percent of the population and 9.1 percent of all homeowners.

Our data provide insights into why Black borrowers were so much less likely to refinance. We find that during the COVID-19 pandemic, basic patterns documented in earlier research (Gerardi, Willen, and Zhang, 2020) continued to hold. Black and Hispanic borrowers have higher exposure to risk factors such as low credit scores and high loan-to-value (LTV) ratios, and these risk factors inhibit refinancing. White and Asian borrowers respond more strongly to reductions in interest rates. Overall, we estimate that, controlling for risk factors, Black and white borrowers were about equally likely to refinance before the pandemic, but Black borrowers were 40 percent less likely than white borrowers to refinance after the pandemic started and interest rates dropped.

The evolution of mortgage nonpayment during the COVID-19 pandemic also displays large disparities. We find that 5.5 percent of the borrowers who had active mortgages in January 2020 were past due in October 2020 as compared with only 1.1 percent for the same period in 2019. For Black borrowers, the October 2020 figure jumps to 12.3 percent as compared with only 4.3 percent for white borrowers. Our analysis shows that this disparity

respectively. See Appendix A for more details on how we classify borrowers in the Home Mortgage Disclosure Act data, which is the sole data source we use that contains borrower race and ethnicity.

${ }^{3}$ See https://www.bls.gov/web/empsit/cpsee_e16.htm.

${ }^{4}$ The Fed initially purchased $\$ 300$ billion of MBS in March 2020. By September 2020 it had purchased approximately $\$ 1$ trillion. Since September 2020, it has purchased $\$ 40$ billion per month. 
reflects both the fact that Black borrowers were more likely to miss payments and also that Black borrowers were less likely to cure past-due loans by either resuming payments or paying off the loans. Of all borrowers who missed payments starting in February 2020, 35 percent of white borrowers were still past due in October of 2020 as compared with 44 percent of Black borrowers. We also find that nonpayment rates rose disproportionately for Asian borrowers. In 2019, Asian borrowers were about half as likely to miss a payment as the population as a whole, but in 2020 Asian nonpayment rates were similar to those of the population. However, as compared with Black borrowers, Asian borrowers were much more likely to cure.

The main policy remedy targeting borrowers who could not make mortgage payments was forbearance. Forbearance occurs when the lender promises to take no action against borrowers who miss payments. Lenders often voluntarily provide forbearance after natural disasters, but Congress mandated it during the COVID-19 pandemic. Specifically, the 2020 Coronavirus Aid, Relief, and Economic Security (CARES) Act stipulated that borrowers could enroll in forbearance by simply attesting to financial hardship caused by COVID-19; borrowers did not need to document this hardship. The forbearance period initially lasted six months, but borrowers could request an extension of an additional six months. ${ }^{5}$ These periods were later extended to 18 months in total.

We find that forbearance provided effective relief across all races and ethnic groups during the pandemic. Specifically, we follow borrowers over the year starting in February 2020 and document five facts about forbearance.

1. Most borrowers who missed payments entered forbearance. Overall, the share was about 81 percent, with a low share of 80 percent for Black borrowers and a high share of 88 percent for Asian borrowers.

2. Most borrowers across all racial and ethnic groups first entered forbearance over a fairly short period of time, from April through June 2020.

3. As intended, most borrowers who took forbearance did not suffer harm to their credit histories. The median credit score for a borrower 60 or more days past due was actually higher in February 2021 than in February 2020, and the increase was slightly higher for Black borrowers than their white counterparts. To gain some perspective from a previous period of mortgage turmoil, we compare the credit score distribution of

\footnotetext{
${ }^{5}$ Section 4022 of the CARES Act mandated that borrowers of federally backed mortgages could request forbearance for up to 12 months. It further stated that "no fees, penalties, or additional interest will accrue on the loan beyond what is scheduled." In February 2021, the Biden Administration extended the CARES Act forbearance mandate through June 2021.
} 
past-due borrowers in February 2021 with the distribution of past-due borrowers in February 2010 and document large differences. In particular, the former distribution is significantly higher, as 61 percent of past-due borrowers in 2021 have VantageScores of less than 660 (considered the cut-off for a "prime" score) compared with 96 percent of past-due borrowers in 2010. More strikingly, 43 percent of past-due borrowers in 2010 had deep-subprime scores (less than 500) versus 6 percent in 2021.

4. Despite accruing months of missed payments, borrowers who entered forbearance typically had higher equity in February 2021 than they did in February 2020. This striking fact results from the historic boom in housing prices during the pandemic as cumulative house price appreciation (HPA) exceeded the accrued arrears due to missed payments for most borrowers. Furthermore, we show that HPA during the pandemic was similar for homeowners of all races and ethnicities, ensuring that increased equity was a broad-based outcome.

5. Lenders have allowed most borrowers exiting forbearance to place arrears in a noninterest-bearing second lien. As a result, the worst-case mortgage payment for a borrower exiting forbearance is the payment due before they entered forbearance, unless they can afford and choose a more aggressive repayment plan.

Together, facts (1) through (5) tell us that the typical borrower who missed a mortgage payment is likely to exit forbearance in a financial condition that is similar to the one they were in before the COVID-19 pandemic, at least as far as their mortgage is concerned: a similar level of equity, similar credit score, and the same monthly payment. This benign outcome is likely to hold for borrowers of all races and ethnic groups subject, of course, to the provision that they applied for and received forbearance from their lender.

Our paper is related to a burgeoning literature on the effects of the COVID-19 pandemic on income and racial inequality in the housing and mortgage markets. For example, Davydiuk and Gupta (2020) find that high mortgage debt inhibited mobility for low-income and minority individuals during the pandemic, especially in states that allow lender recourse. Agarwal, Chomsisengphet, Kiefer, Kiefer, and Medina (2020) document large differences between high- and low-income borrowers in the propensity to refinance during the pandemic period, which resulted in large disparities in mortgage interest savings. Fuster, Hizmo, Lambie-Hanson, Vickery, and Willen (2021) find that interest rate premiums for Federal Housing Administration (FHA) borrowers increased during the pandemic, especially for lowcredit-score FHA borrowers, which may have reduced the refinance incentive for some lower income households. 
Missed mortgage payments are an imperfect measure of household financial stress. Research shows that borrowers facing severe adversity typically continue to make their mortgage payments. Gerardi, Herkenhoff, Ohanian, and Willen (2018) looks at a sample of borrowers who faced a choice of skipping a mortgage payment or cutting consumption down to subsistence levels and find that only 20 percent opted to default. At the same time, so-called strategic defaulters choose to skip affordable payments if the financial benefits outweigh the costs.

An, Cordell, Geng, and Lee (2021) and Durbin, Li, Low, and Ricks (2021) document racial disparities in nonpayment rates. An et al. (2021) argue that government forbearance policies have mitigated some of those differences, as low-income and minority households used forbearance to a greater extent during the pandemic. We build on their findings, showing that the differential entries into nonpayment and forbearance are further exacerbated by slower exits out of forbearance, as Black borrowers in particular have been slower than white borrowers to cure or pay off their mortgages. Sustainability of home ownership for these long-term-past-due borrowers is a concern unless labor market conditions improve before forbearance expires in September 2021. Furthermore, borrowers who remained behind on payments during the pandemic may have missed out on low-interest rate refinancing opportunities. In effect, borrowers who could use the payment reductions the most moving forward may be the least likely to obtain them.

\section{Data}

In order to track mortgage performance over time by borrower race and ethnicity, we combine several sources of anonymized data: Black Knight McDash mortgage servicing data, Home Mortgage Disclosure Act (HMDA) data, and two credit bureau data sets from Equifax: Credit Risk Insight Servicing data linked to McDash data (known as "CRISM") and the Federal Reserve Bank of New York/Equifax Consumer Credit Panel (CCP). The McDash database is constructed using information reported by mortgage servicers. It covers more than 60 percent of the U.S. mortgage market (in some years as much as 80 percent) during our sample period and contains detailed information on underwriting characteristics at origination (for example, credit scores, loan-to-value ratios, debt-to-income ratios). In addition, each loan is tracked at a monthly frequency in the McDash database from the month of origination until the loan is paid off, and detailed performance information is provided each month that the loan is active. In most of our analysis, we focus on the loan performance from January 2019 through February 2021.

We first match McDash mortgage performance data for 30-year, fixed-rate, first-lien loans 
originated during the 2010-2019 period with HMDA data to identify the race, ethnicity, and gender of the borrower and to capture borrower income at the time of underwriting. We restrict our sample to mortgages secured by owner-occupied, single-family homes and condos. We further limit the sample to FHA loans and conventional loans held by Fannie Mae or Freddie Mac (government-sponsored enterprises, or GSEs). ${ }^{6}$ We also exclude all mortgages that are in the "super-conforming" category. ${ }^{7}$

The vast majority (approximately 90 percent) of McDash loans are linked to records in the CRISM data, which provides information on the outstanding mortgages and other debt included in monthly credit reports, and which can be used to distinguish between mortgage payoffs that occur due to refinance or another form of prepayment, such as moving and selling the home. ${ }^{8}$ Neither the McDash nor CRISM data include direct indicators of forbearance, so we also match the HMDA-McDash-CRISM data set to primary consumers in the CCP. Approximately 5 percent of the borrowers in the HMDA-McDash-CRISM data set are included in the CCP, so we restrict our analysis to this subset only when examining forbearance. See Appendix A for information on how we derive forbearance in the CCP.

Finally, we use two additional sources of supplementary data in our analysis. We use data from Optimal Blue to estimate the interest rate that borrowers would likely receive upon refinancing. ${ }^{9}$ To do this, we use the median interest rate locked each month by borrowers with similar credit scores and loan-to-value (LTV) ratios, as captured in the Optimal Blue database. ${ }^{10}$ We use CoreLogic Solutions house price indices at the Zip code, county, and state levels to analyze recent trends in home price appreciation for our mortgage sample and to calculate updated monthly LTV ratios. ${ }^{11}$

Table 1 gives an overview of our sample. Seven percent of the loans are to Black borrowers, and 10 percent are to Hispanic borrowers. Black and Hispanic borrowers have income

\footnotetext{
${ }^{6}$ We uniquely match 82 percent of McDash mortgages in our sample to mortgages in the HMDA data. In other words, only one McDash mortgage matches a particular HMDA origination, and that HMDA loan matches only that loan in McDash.

${ }^{7}$ This was a loan category created by the Economic Stimulus Act of 2008 that allowed the GSEs to purchase mortgages in "high cost" housing markets. These loans exceed the national conforming loan limits.

${ }^{8}$ CRISM provides the borrower's credit bureau information beginning six months before the McDash loan is originated and ending six months after the loan is terminated. We use the borrower's credit information after the McDash loan is terminated to determine if the prepayment corresponds to a refinance or a home sale.

${ }^{9}$ Optimal Blue data (as referenced throughout) is anonymized mortgage market/rates data that do not contain lender or customer identities or complete rate sheets.

${ }^{10} \mathrm{We}$ calculate the rate assuming the borrower pays zero points (and receives zero credits) from the lender at closing. We observe the borrower's credit score in month $t$ in the CRISM data, and we estimate the LTV ratio of their mortgage by dividing its unpaid principal balance by the estimated value of the home.

${ }^{11}$ We do this by adjusting the property value at origination by the growth in the CoreLogic Zip code home price index. The CoreLogic county-level index is then used for loans located in Zip codes for which CoreLogic does not provide an index, and the state-level index is used if neither Zip code nor county data are available.
} 
at origination roughly 20 percent lower than white and Asian borrowers and are much more likely to use FHA. Much of our analysis focuses on loans active during the pandemic. Immediately before the pandemic, the typical Black or Hispanic borrower had a lower credit score and higher leverage than their white and Asian counterparts.

\subsection{Summary of Outcomes}

Table 2 displays raw outcomes for two samples of loans in our data: a pre-pandemic sample and a pandemic sample. Panel A shows outcomes for the pandemic sample, which consists of loans that were active in January 2020, while Panel B displays outcomes for the prepandemic sample, consisting of loans that were active in January 2019. For both samples, we follow the loans over the subsequent 10 months and calculate the fraction of each sample that terminates and the fraction that remains active through October of each respective year, broken down by each of our borrower race/ethnicity categories. ${ }^{12}$ We distinguish between five different types of terminations: (1) a refinance, (2) a payoff in which the borrower does not move, (3) a payoff in which the borrower moves and originates a new mortgage (likely corresponding to the purchase of a new home), (4) a payoff in which the borrower moves but does not take on new mortgage debt (likely corresponding to a transition into the rental market), and (5) a foreclosure. We also distinguish between loans that are active and either current on payments or behind by one payment versus those that are behind by at least two payments (60-plus days past due).

Table 2 displays some notable patterns. First, of the 4.9 million GSE and FHA loans that were active in our sample as of January 2020, 11.0 percent were refinanced by the end of October 2020. In comparison, although interest rates were also falling in the first half of 2019, just 3.2 percent of loans active in January 2019 were refinanced through October 2019. While refinance shares were roughly similar across the race/ethnic groups in 2019, there were large differences in 2020. A significantly lower fraction of Black (6.2 percent) and Hispanic (8.9 percent) households refinanced in the pandemic sample compared with white (11.6 percent) and Asian (13.6 percent) borrowers. Second, there were minimal numbers of terminations due to foreclosure in both samples. In the pre-pandemic period, this was due to robust economic conditions, while in the pandemic period there was a nationwide foreclosure moratorium in place. Third, the share of delinquencies is five times greater in the pandemic sample (5.5 percent compared with 1.1 percent), reflecting the large increase in unemployment that occurred at the onset of the pandemic in March 2020. Looking across

\footnotetext{
${ }^{12}$ As explained in Appendix A, we require four months of post-payoff credit bureau data to look for moves and new originations. As a result, we can distinguish between different types of payoffs through only October 2020.
} 
race/ethnic categories, we see that the increase in delinquencies was much larger for minority borrowers, including Asian households, who experienced more than a tenfold increase over the two periods (0.5 percent to 5.5 percent). Finally, in Panel A, we see that forbearance was extremely common for past-due loans, and that this is true across all race/ethnic groups in our sample. Approximately 80 percent of Black and white borrowers who were at least 60 days behind on their payments took advantage of forbearance, while an even greater fraction of Hispanic and Asian borrowers used forbearance (83.5 percent and 87.6 percent, respectively). As described in Dettling and Lambie-Hanson (2021), borrowers who are past due but in forbearance programs are not considered delinquent in credit bureau reporting. Given that the majority of past-due loans during the pandemic were in forbearance, moving forward we use the terms "nonpayment" and "past due" rather than "delinquent."

In the remainder of the paper we will delve deeper into these patterns and focus specifically on the racial disparities in loan outcomes that are apparent in Table 2.

\section{Racial Disparities in Refinances}

In this section we study differences in refinance propensities across race during the pandemic. We first measure the differences and the reasons for those differences. Then in subsection 3.1, we calculate the consequences of these differences as reflected in the distribution of payment reductions across households.

Our analysis of differences in refinance behavior is motivated by Gerardi, Willen, and Zhang (2020), who provide evidence that racial disparities in refinance behavior are significantly exacerbated during periods of low interest rates and high refinance volume. ${ }^{13}$ Low mortgage interest rates fueled significant refinance activity in 2020, with mortgage refinance applications reaching levels not seen since 2009, as shown in panel B of Figure 1.

Table 2 shows that pre-existing racial gaps in refinancing widened during the pandemic. Figure 2 shows the evolution of refinance propensities during the pandemic by plotting monthly, unconditional refinance rates for our different racial and ethnic groups. Refinance rates were similar across all groups in the first few months of 2020, before the onset of the pandemic. Beginning in March 2020, however, a gap emerged between white/Asian borrowers and Black/Hispanic borrowers. Similar patterns appear for both conforming loans held by the GSEs (Panel A) and FHA loans (Panel B), where Black and Hispanic borrowers account for a larger share of outstanding loans.

To assess the sources of these differences, we estimate a logit regression of the likelihood of refinance. In Table 3, we report estimated odds ratios from the regression. Our specification

\footnotetext{
${ }^{13}$ Their analysis does not include the pandemic period.
} 
includes key predictors of refinance: borrower credit scores (VantageScore 3.0), the amount of equity borrowers have in their homes, refinance incentive (how much their rate differs from what is available in the market), and geographic location (and thus, potentially the impact of the COVID-19 pandemic on their employment status). We include a full set of race dummies as well as the interaction of those dummies with Pandemic, which is an indicator variable that takes a value of 1 for months after February 2020 and 0 before. The Pandemic odds ratio tells us how much refinance hazards increased for white borrowers during the pandemic period compared with the pre-pandemic period, while the interactions tell us how much more or how much less the refinance hazards increased for the other groups relative to white borrowers. In columns (1) through (2) of the table, we pool together GSE and FHA loans. In column (1) we do not include controls, while in column (2) we condition on a large set of underwriting characteristics as well as vintage (origination year-quarter) and geographic (state) fixed effects. We also control for whether the borrower had been recently past due (was behind on payments in $t$-3 to $t$-1) or was current during that time but had previously been past due, in $t$-11 to $t$-4, interacted with Pandemic, since missed payments can make borrowers ineligible to refinance and could signal unobserved job or income loss that could also preclude a borrower from refinancing.

According to column (1), the unconditional odds of refinancing for white borrowers increased by a factor of 3.8 during the pandemic compared with 2.5 for Black borrowers (3.777 $\times 0.651)$ and 2.9 for Hispanic borrowers $(3.777 \times 0.773)$. These estimates are consistent with the patterns that we saw in Figure 2. Conditioning on underwriting and borrower characteristics in column (2), the odds of white borrowers refinancing increased in the pandemic by a factor of approximately 1.6, while the conditional odds for Black borrowers did not change $(1.614 \times 0.673 \approx 1)$. We see similar patterns in columns $(3)$ and $(4)$, where we consider GSE and FHA loans separately. The disparity in the increase in refinance hazards for white borrowers versus the increase for Black and Hispanic borrowers during the pandemic is slightly smaller in the FHA sample, which is also apparent in Figure 2.

As shown in column (2), before the pandemic borrowers who had missed a payment in the previous year were about 40 percent less likely to refinance. How long ago the borrower had been behind on payments did not matter much - being recently past due (being behind on payments in the last three months) and having been past due within the previous 11 months but having cured at least four months ago had a similarly sized negative impact on the likelihood of refinancing. However, in the pandemic, missed payments were an even stronger indicator that a borrower would be unlikely to refinance. In particular, during the pandemic, borrowers were more than 80 percent (odds of 0.585 x $0.320=0.187$ ) less likely to refinance if they had missed payments in the last three months than if they had been 
current on payments over the last year. Borrowers who had missed payments but cured and stayed current for the last three months were about half as likely to refinance as someone who had not missed payments $(0.619 \times 0.744=0.46)$.

The significance of being recently past due on pandemic-era refinancing is intuitive for two reasons. First, most of these borrowers took forbearance, and GSE and FHA loans in forbearance are typically ineligible for refinancing until they have left forbearance and stayed current for three months. Second, having been past due on mortgage payments in the last three months may signify recent unemployment or reduced income, which could make it difficult to qualify for a refinance. Importantly, however, controlling for recent missed payments does not explain away the refinance gap between Black or Hispanic borrowers and white borrowers, which is important to test, since minority borrowers experienced higher rates of mortgage distress during the pandemic that are not reflected in credit scores.

\subsection{Refi Savings and Money Left on the Table}

In this subsection, we calculate the financial impact of racial and ethnic differences in refinance propensities documented above. To do this, we conduct the following exercise. First, we assume borrowers can refinance to a new 30-year mortgage and receive the average zero-point mortgage interest rate locked by borrowers with their same VantageScore and loan-to-value ratio as of the month in question. We assume refinance closing costs are 1 percent of the mortgage balance plus \$2,000, following Agarwal, Driscoll, and Laibson (2013), and that these costs are rolled into the principal balance of the new mortgage. We then focus our attention on all borrowers who were "in the money" to refinance, which we define as situations in which the borrower can refinance with a new rate that is at least 75 basis points (bps) lower than their existing rate, and their monthly mortgage payment falls by at least 5 percent and a minimum of $\$ 50$. We then define refinance benefit as the monthly payment reduction associated with a rate-and-term refinance to the new rate described.

Three aspects of our calculation merit further explanation. First, our data allow us to identify borrowers who refinanced and the size of the new loan, but our data do not provide us with any information on the terms of the new loan. Second, we can assume that a refinance is rate-and-term without loss of generality because, to a first approximation, the present value of the cash flow from a refinance is independent of whether a borrower takes the benefit in reduced payments or increased cash up front. Third, we limit our attention to borrowers who are "in the money" because we want to focus on the benefits of lower interest rates. "Out of the money" refinances are not irrational but rather reflect motivations other than lower interest rates. Examples of non-interest-rate motivations for refinancing 
include a cash-out driven by house price appreciation or a cash-out driven by individual economic shocks such as college tuition payments and individual rate reductions resulting from improved creditworthiness or increased equity. Taking the difference of the refinance rate and the in-the-money refinance rate (the line labeled "Refinanced "in the money" in Panel (3) of Table 2) shows that the out-of-the-money refinance rate remained essentially the same in 2020 as it was in 2019 (about 2 percent of borrowers), vindicating our focus on the in-the-money borrowers. Panel (3) also shows that cash-out refinances grew by about 50 percent from 2019 to 2020 as compared with non-cash-out refinances, which increased by a factor of nearly 5 .

The line labeled "Refinanced 'in the money'" in Panel (3) of Table 2 shows that white and Asian borrowers were much more likely than Black and Hispanic borrowers to take advantage of low interest rates. This difference is attenuated a bit by the fact that Black and Hispanic borrowers are more likely to be in the money, partly because they are less likely to have refinanced in the past. If we condition on being in the money, the refinance gap between Black and white borrowers increases by about 1 percentage point.

Panel (4) of Table 2 computes the payment savings for borrowers in different racial and ethnic groups. We report the mean monthly payment reductions for borrowers, which are generally similar across groups. White borrowers generally have lower existing interest rates, which lowers the gain from refinancing, but they also have bigger mortgages, which works in the opposite direction. We then annualize the savings and multiply them by our estimate of the number of mortgages held by each racial and ethnic group. Overall, we estimate that American homeowners who refinanced will save about $\$ 5$ billion every year until they refinance again or sell their homes. We estimate that Black homeowners account for only $\$ 198$ million, or 3.7 percent, of the savings.

Our sample ends in October 2020, and the refinance boom lasted until February 2021 (after which refinance volume fell, although it remained elevated by historic standards). Although we cannot identify refinances in that period, we can get some sense of the refinancing patterns by looking at overall prepayment behavior. Over the year from February 2020 to February 2021, we estimate that Black borrowers accounted for about 3.9 percent of prepayments, not far off the 3.8 percent share of in-the-money refinances for Black borrowers recorded in the first line of Panel (4).

\section{Mortgage Nonpayment and Forbearance}

Figure 3 displays monthly, unconditional nonpayment rates for GSE and FHA loans from January 2019 through the end of our sample (February 2021) broken down by race/ethnicity. 
We use a 60-plus days past due (DPD) definition of nonpayment (that is, at least two missed payments), which is common in the mortgage default literature. Panel A displays the stock of mortgage nonpayments (the share of active mortgages that are at least 60 DPD in each month), and panel $\mathrm{B}$ displays the flow of new mortgage nonpayments (the share of loans in each month that transition into 60 DPD). The differences across race in the pattern of nonpayment hazards is striking. Nonpayment rates spike for all borrowers beginning in May 2020 with the onset of the pandemic, but the increase is significantly larger for borrowers of color. ${ }^{14}$ Black borrowers experienced the most distress; their nonpayment rates associated with GSE loans rose from around 1 percent before the pandemic to 9 percent in mid-2020, while their nonpayment rates in the FHA sample rose from about 5 percent to almost 20 percent. Hispanic and Asian borrowers experienced a similarly sharp rise in nonpayments, while white borrowers experienced less distress; their nonpayment rates rose by about half as much as those of Black borrowers. In total, 15.6 percent of Black borrowers who had been current on payments at the start of the pandemic had missed payments by February 2021, as compared with 6.5 percent of white borrowers, 9.9 percent of Asian borrowers, and 13.3 percent of Hispanic borrowers.

Panel B of Figure 3 shows that entries into mortgage distress were concentrated almost entirely within a two- to three-month period at the very beginning of the pandemic. New mortgage nonpayments for all borrowers in both market segments spike in May 2020, remain elevated in June, but then quickly decline in July. New nonpayments flatten afterward at levels that are slightly more elevated relative to their pre-pandemic levels. The fact that we see the stock of 60 DPDs stay extremely elevated in Panel A through the end of the sample despite the flows into nonpayment receding in the summer of 2020 suggests that many borrowers who experienced distress at the beginning of the pandemic were unable to cure. We show below that most of those borrowers obtained relief with the CARES Act forbearance policy, and many remain in forbearance through the end of our sample.

In Table 4, we estimate logit models of entry into $60 \mathrm{DPD}$ to see how the disparities across race change when we condition on borrower and loan characteristics. Column (1) displays unconditional odds ratios, which are consistent with the patterns that we observed in Figure 3. The unconditional odds of nonpayment for white borrowers increased by a factor of more than 8 in the pandemic period, while the odds for Black borrowers, which were significantly higher in the pre-pandemic period (approximately three times higher) than the odds for white borrowers, increased by slightly less (a factor of 6.7). In contrast, the odds of nonpayment for Asian borrowers, which were lower than the odds for white borrowers

\footnotetext{
${ }^{14}$ The spike in 60 DPD in May 2020 corresponds to borrowers missing their first payment at the beginning of April and second payment in May.
} 
before the pandemic, increased by significantly more (a factor of almost 23). The patterns across race/ethnic groups continue to hold when we include covariates in column (2). Finally, columns (3) and (4) estimate separate logit models for GSE and FHA borrowers. Similar patterns of 60 DPD rates across race/ethnic groups hold in both samples.

These results clearly show that minority borrowers experienced higher levels of mortgage distress compared with white borrowers during the COVID-19 pandemic. While the odds of nonpayment for Black borrowers increased by slightly less than those for white borrowers, pre-pandemic nonpayment rates for Black borrowers were much higher, and thus their 60 DPD rates during the pandemic remained at much higher levels, as evidenced in Figure 3. In contrast, nonpayment rates for Asian borrowers were lower in the pre-pandemic period, but then grew significantly faster relative to those for white borrowers during the pandemic.

As we discussed above, the primary policy response to the increase in mortgage distress during the pandemic was to provide a forbearance option to all borrowers with loans guaranteed by the federal government. Figure 4 plots forbearance rates by race/ethnicity. The increase in forbearance rates roughly mirrors the increase in nonpayment rates that we see in Figure 3. Before the pandemic virtually no borrowers were in forbearance plans, but with the onset of the pandemic, forbearance usage increased dramatically, with more than 10 percent of white borrowers and almost 20 percent of minority borrowers with FHA mortgages taking advantage of the payment relief.

What has happened to borrowers who missed payments during the pandemic? This is a crucial question, which we try to address in Table 5. In the table, we focus on borrowers who became 60 DPD in May and June 2020, as Figure 3 clearly shows that the vast majority who missed payments in the pandemic became 60-plus DPD in that two-month period. In Panel A we follow loans through February 2021 and show the fraction that are still at least one payment behind (30-plus DPD), the share that were cured and are current, and the fraction that were prepaid (voluntarily). ${ }^{15}$ In Panel B we follow loans through October 2020 and show a more detailed breakdown of the loans that were paid off, since we have information to distinguish between refinances and sales through October. In both panels, we also show the fraction of loans that were enrolled in a forbearance policy, conditional on being 30-plus DPD.

Table 5 offers some important takeaways. First, the majority of distressed borrowers had either cured or paid off their loans by February 2021. More than 51 percent of borrowers who were in distress in May and June 2020 had resumed making their monthly payments by February 2021, and almost 12 percent had voluntarily paid off their loans. However, a

\footnotetext{
${ }^{15}$ There were no involuntary prepayments during this time period due to the nationwide foreclosure moratorium.
} 
sizeable fraction of borrowers were still at least one month behind on payments (37 percent). In Panel B we see that the modal type of the payoff (as of October 2020) involved borrowers moving without obtaining a new mortgage (likely transitions into the rental market). As of October 2020, only 1.3 percent of borrowers who had experienced distress in the pandemic were able to refinance. This group likely resumed payments quickly after becoming 60plus DPD, as the GSEs and FHA currently require a minimum of three months of timely payments to qualify for refinancing. There is also a nontrivial fraction of payoffs for which we do not see new mortgage debt or a change of address that would signify a move. Some of these borrowers may have moved or refinanced, but indicators of these changes were not reflected on their credit reports as of February 2021. Very few borrowers paid off their loan and purchased another home.

The rest of the table shows that, once again, the aggregate percentages mask some significant differences across racial/ethnic groups. In particular, there are large disparities in the outcomes of Black borrowers compared with white borrowers. Black borrowers were both less likely to resume making payments and significantly less likely to pay off their loans. Panel A shows that only 6.8 percent of Black borrowers had prepaid by February 2021 compared with 13.5 percent of white borrowers. In addition, the fraction of white borrowers who had resumed making their payments is higher than Black borrowers (51.5 percent versus 49.2 percent). These differences resulted in an almost 9 percentage point gap between Black and white borrowers in terms of the share of borrowers who were still behind on their mortgage payments at the end of our sample. ${ }^{16}$

Finally, the table shows that, conditional on being past due on payments at the end of the sample period, similarly high fractions of minority and white borrowers were enrolled in forbearance plans. For example, as of February 2021, almost 89 percent of all white borrowers who were 30-plus DPD were enrolled in forbearance, compared with 86 percent of Black and Hispanic borrowers and 88 percent of Asian borrowers. This suggests that the reason that overall forbearance rates are significantly higher for minority borrowers (Figure 4) during the pandemic is due to higher nonpayment rates and not because of higher forbearance enrollment rates.

\footnotetext{
${ }^{16}$ In Appendix B we plot cure hazards for past-due borrowers and estimate a logit model for cures. Cure rates for Black borrowers were significantly lower than for white borrowers, and the gap does not significantly change during the pandemic.
} 


\section{Are Foreclosures Likely to Rise in the Post-Pandemic Period?}

Even though historically high job losses drove significant increases in mortgage distress, foreclosure starts remained at minimal levels (Figure 1) due to the combination of widespread forbearance and a national moratorium on foreclosures. However, the government forbearance mandate is set to expire in September 2021, and the national moratorium on foreclosures is set to expire in June 2021. Thus, there is concern that many borrowers will still be in financial distress and unable to resume making mortgage payments when the policies end, which could result in a foreclosure crisis similar to what occurred a decade ago in the aftermath of the Global Financial Crisis (GFC).

In this section we provide evidence that most borrowers, including those that are in distress and behind on their payments, have accumulated significant home equity due to recent, robust house price appreciation. This suggests that unlike in the aftermath of the GFC, most borrowers who are now in distress are unlikely to experience foreclosure after they exit forbearance. However, we will show that there are significant differences across race/ethnic groups, as minority borrowers do have less housing equity on average.

Finally, we provide descriptive evidence on credit scores during the pandemic period and show that widespread forbearance uptake seems to have mitigated the typical adverse effects that mortgage delinquency has on credit histories. This may play an important role in allowing borrowers who have missed payments due to financial distress to retain access to credit markets. In addition, it could make it easier for a borrower who sells their house due to pandemic distress to purchase another home in the future.

\subsection{House Price Growth and the Equity Distribution}

While widespread distress in the mortgage market may well persist until unemployment falls back to its pre-pandemic levels, another foreclosure crisis is unlikely due to the fact that most borrowers have accumulated significant equity in their homes. House prices rose in the pre-pandemic period and in many areas accelerated during the pandemic, providing a greater equity cushion to help borrowers refinance, extract equity, and avoid future foreclosures.

Table 6 shows summary statistics for the distribution of house price growth by race/ethnic group from February 2020 through February 2021 (Panel A). Among borrowers in our sample whose loans were still active in February 2021, the median appreciation in their area over the next year was 9.8 percent, and the average was 10.2 percent. The table shows that house

price growth was widespread, as even the 10th percentile of the distribution experienced 
more than 5 percent appreciation during the pandemic. ${ }^{17}$ One striking feature of the table is how little heterogeneity there is across race/ethnic groups. Median house price growth was lowest among Asian borrowers but still reached 9.2 percent, while it was highest among white borrowers but by less than 1 percentage point.

Using the CRISM data, we can estimate borrowers' combined loan-to-value (CLTV) ratios, factoring in first liens as well as junior lien mortgages and updating the home value at origination by the amount of growth in the area house price index. For borrowers with past-due mortgage payments, we estimate the unpaid principal, interest, taxes, and insurance that have accrued and include those in the borrowers' estimated total mortgage debt. With an estimate of CLTV for each mortgage in our sample, we are able to compute borrower equity levels. ${ }^{18}$ In Panel B of Table 6, we display summary statistics of the equity distribution for loans that were active as of February 2021. The table shows that the vast majority of borrowers in our sample have accumulated a significant amount of housing wealth. The median value of equity in our sample is 45.2 percent. There is significant variation across race/ethnic groups, however, as the median Black borrower and median Hispanic borrower have accumulated significantly less equity (39.0 percent and 41.6 percent, respectively).

Importantly, unlike with the GFC and Great Recession, our sample includes very few borrowers with negative equity. Table 6 shows that even borrowers at the 5 th percentile of the equity distribution have accumulated significant wealth in their homes. This suggests that most borrowers are unlikely to be at risk of foreclosure, as they would have the option to sell their properties in the event that they are unable to resume making mortgage payments due to financial distress.

In Figure 5, we take a closer look at this issue by computing the distribution of equity after accounting for transactions costs that homeowners typically face when selling their homes. Specifically, we assume that transactions costs due to selling and moving are 8 percent of the value of the property and subtract those costs from our estimate of borrower equity. We display the distribution of equity (in $\$$ ) net of transactions costs for borrowers who are either current or less than 60 DPD on their mortgages (left panel) and for borrowers who are behind on their payments (right panel). In both panels, we display the distributions separately for Black and white borrowers. The figure suggests that the vast majority of borrowers would have positive equity, even after we account for the transaction costs involved in selling and

\footnotetext{
${ }^{17}$ These estimates are based on CoreLogic Solutions home price indices (HPIs). For 85 percent of borrowers, indices are available at the Zip-code level. For 15 percent, the county-level home price index is used. For the remaining 5 percent, the state-level index is used to estimate price appreciation. Results in Table 6 are nearly identical when they are restricted to just those for the 85 percent of borrowers with Zip-code-level HPIs.

${ }^{18}$ We compute equity as: Equity $y_{i t}=\frac{H V_{i t}-M_{i t}}{H V_{i t}}=1-C L T V_{i t}$, where $H V_{i t}$ is the current value of property $i$ at time $t$, and $M_{i t}$ is the remaining mortgage balance associated with property $i$ at time $t$.
} 
moving. However, the figure shows large discrepancies between the equity distributions for Black and white borrowers. There is a much larger mass of Black borrowers toward the left tail of the distribution. In particular, we estimate that about about 10 percent of Black borrowers and 6 percent of white borrowers who were behind on their payments in February 2021 would have negative equity after we account for transactions costs and interest, taxes, and insurance that have accrued during nonpayment.

\subsection{Credit Scores}

The CARES Act of 2020 included language that protects borrowers who choose to use forbearance from experiencing a negative impact on their credit scores. Specifically, the legislation says that if a borrower is in a forbearance plan, the lender must report the loan as current to the credit bureaus. ${ }^{19}$ In this section we show that this stipulation dramatically affected the credit scores of borrowers who missed mortgage payments during the pandemic period.

Figure 6 plots the distribution of credit scores (VantageScore 3.0) for borrowers who are 60-plus DPD, comparing the distributions in February 2010, in the aftermath of the GFC, and February 2021. The differences between the distributions is striking. In February 2010, about 90 percent of past-due borrowers had scores below 600, whereas just 37 percent of had scores below 600 in February 2021. The majority of these borrowers began missing payments in April and May 2020 and used forbearance under the CARES Act, which enabled them to avoid the serious damage to their scores that would normally accompany missing months of mortgage payments.

Although we are unable to construct a version of Figure 6 separately for each race/ethnic group (due to data constraints), we can look at the distribution of recent VantageScore changes during the pandemic period separately by race. Figure 7 does this for the sample of borrowers who are behind on their payments and the sample who are current on their payments. The figure shows that most borrowers behind on payments experienced either an increase or no change in their VantageScore from February 2020 through February 2021, and that there are only small differences between Black and white borrowers.

Taken together, the evidence in Figures 6 and 7 suggests that the VantageScores of distressed mortgage borrowers of all races are significantly higher now compared with such scores in the aftermath of the GFC. This has important implications, as it suggests that coming out of the pandemic, distressed mortgage borrowers should have more robust access to consumer credit markets and a greater ability to tap into their housing wealth. In addition,

\footnotetext{
${ }^{19}$ See section 4021 of the Coronavirus Aid, Relief, and Economic Security Act, which can be found at https://www . congress.gov/116/bills/hr748/BILLS-116hr748enr.pdf
} 
borrowers who are not able to cure their distress and forced to sell will likely face an easier return to home ownership in the future compared with similarly distressed borrowers a decade ago.

\subsection{Forbearance Exits}

Borrowers who obtain forbearance build up significant arrears, and those arrears must be paid before the borrower can exit forbearance and become current again. While some borrowers can repay the arrears in a lump sum or in a small number of installments, most cannot. The insurers of all the loans in our sample have provided a waterfall of options starting with "payment deferral," offered essentially to all borrowers in forbearance. ${ }^{20}$ The key component of payment deferral is the placement of all arrears in a non-interest-bearing second lien. The arrears include all principal and interest and any taxes and insurance payments made by the servicer on behalf of the borrower. The second lien is due on termination of the mortgage either through refinance of the mortgage or sale of the property. After the creation of the second lien, the borrower's mortgage is reinstated as if the borrower had made all their payments during forbearance. In other words, for a fixed-rate mortgage, the first payment due after the end of forbearance will be exactly the same as the last payment due before the start of forbearance.

\section{Conclusion}

The COVID-19 pandemic roiled labor markets and created extreme financial distress for many households. While the U.S. housing market fared remarkably well during the pandemic, many financially distressed mortgage borrowers had trouble meeting their payment obligations. The dramatic spike in mortgage nonpayment and forbearance use is well documented, but little research has been conducted on racial disparities in the mortgage market during the pandemic period.

Using a custom data set that links detailed microdata on mortgage performance, sociodemographic data, and data on consumer credit and area house price appreciation for 5.6 million mortgages, this paper documents significant racial disparities in mortgage outcomes during the COVID-19 pandemic. Black and Hispanic borrowers were much less likely to

\footnotetext{
${ }^{20}$ Details on payment deferral can be found for the relevant loans at https://files.hudexchange. info/course-content/housing-counseling-webinar-cfpb-mortgage-forbearance-process/

Home-Retention-Exits-COVID-19-Related-Forbearances.pdf for FHA/VA/USDA, https: //sf.freddiemac.com/working-with-us/servicing/servicing-solutions/payment-deferral for Freddie Mac, and https://singlefamily.fanniemae.com/media/22936/display for Fannie Mae.
} 
refinance their loans and take advantage of falling interest rates during the pandemic. In addition, minority borrowers were much more likely to experience mortgage distress during the pandemic period, leading to significantly higher nonpayment and forbearance rates. To date, cures of nonpayments have been particularly low for Black borrowers, indicating that they have experienced the pandemic's most persistent mortgage distress.

While nonpayment and forbearance rates remain extremely elevated, strong house price appreciation over the course of the pandemic has left the majority of mortgage borrowers with significant housing equity. As a result, the housing market is unlikely to experience another foreclosure crisis, as most borrowers in financial distress should be able to avoid foreclosure by either selling or extracting equity to alleviate temporary cash-flow disruptions. However, an important caveat to this point is that minority borrowers have accumulated less housing equity than white borrowers and thus may be at higher risk of foreclosures when forbearance plans wind down. 


\section{Panel A: Mortgage Nonpayment and Foreclosure: 2000-Present}

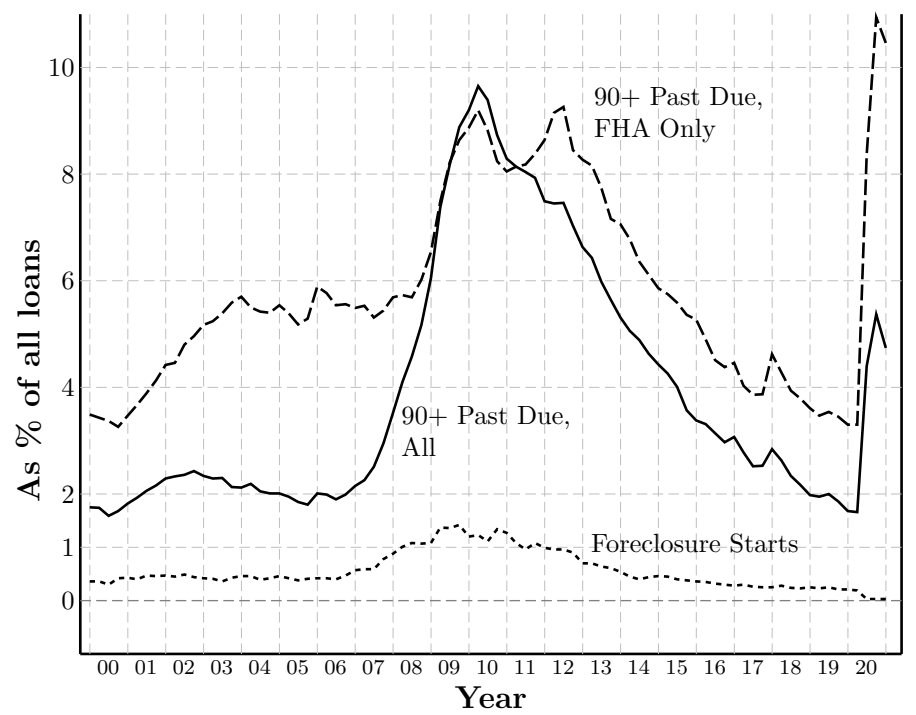

Panel B: Refinances and Quantitative Easing: 2000-Present

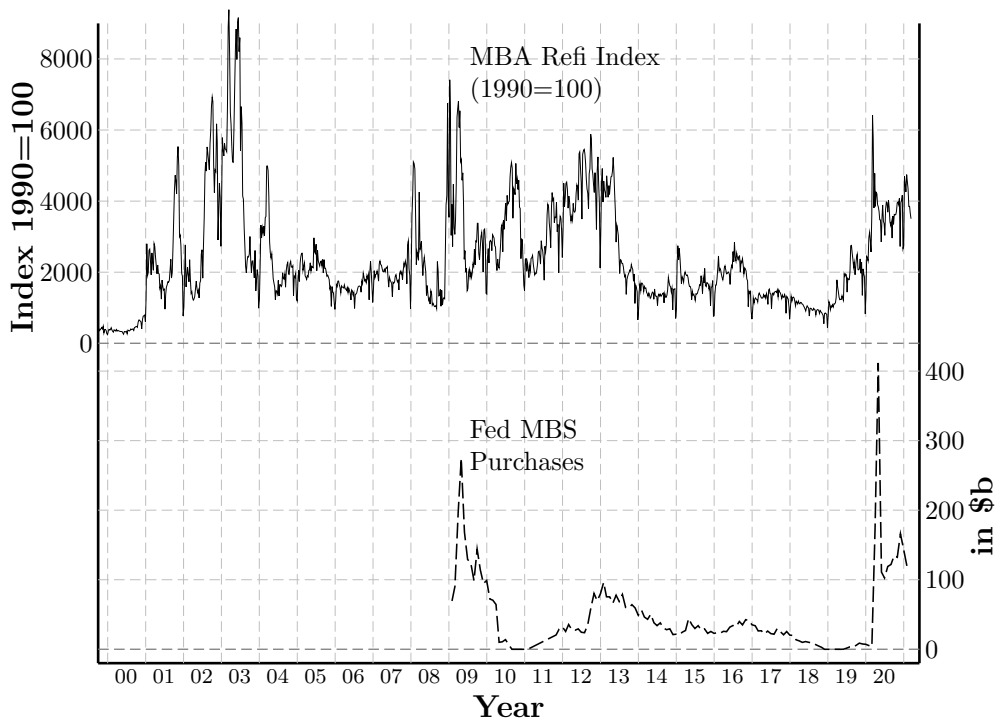

Figure 1: Panel A: Past-due and foreclosure starts reported by the Mortgage Bankers' Association (MBA) National Delinquency Survey: https://www.mba.org/ news-research-and-resources/research-and-economics/single-family-research/ national-delinquency-survey. 90+ Past Due includes all past-due loans, including loans in foreclosure. Panel B: MBA Refi index comes from the MBA Weekly Applications Survey: https://www.mba.org/news-research-and-resources/research-and-economics/ single-family-research/weekly-applications-survey. Fed MBS purchases include all purchases in the New York Fed Agency Mortgage-backed Securities Purchase Program as compiled by Haver Analytics (series FRT@USECON). 

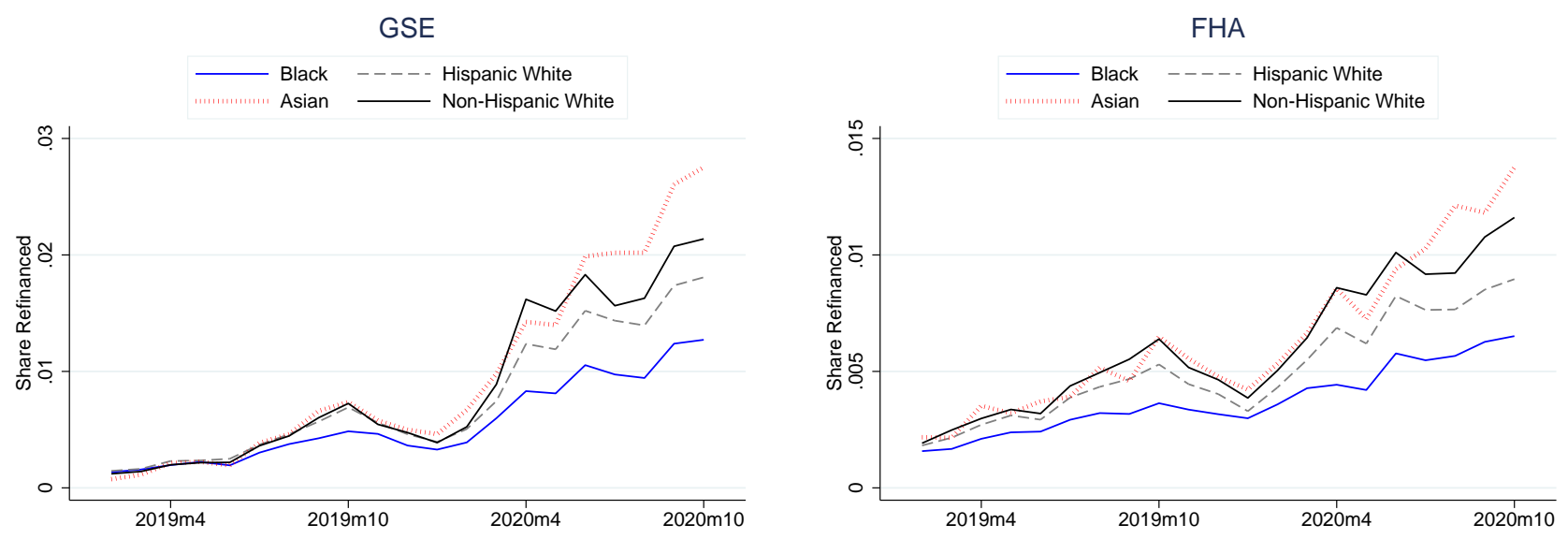

Figure 2: Monthly Refinance Rates for GSE and FHA Loans

Data sources: Home Mortgage Disclosure Act (HMDA) data and Equifax Credit Risk Insight ServicingMcDash (CRISM) data. Borrower race and ethnicity are captured in HMDA. Refi indicators are derived using data from CRISM. 

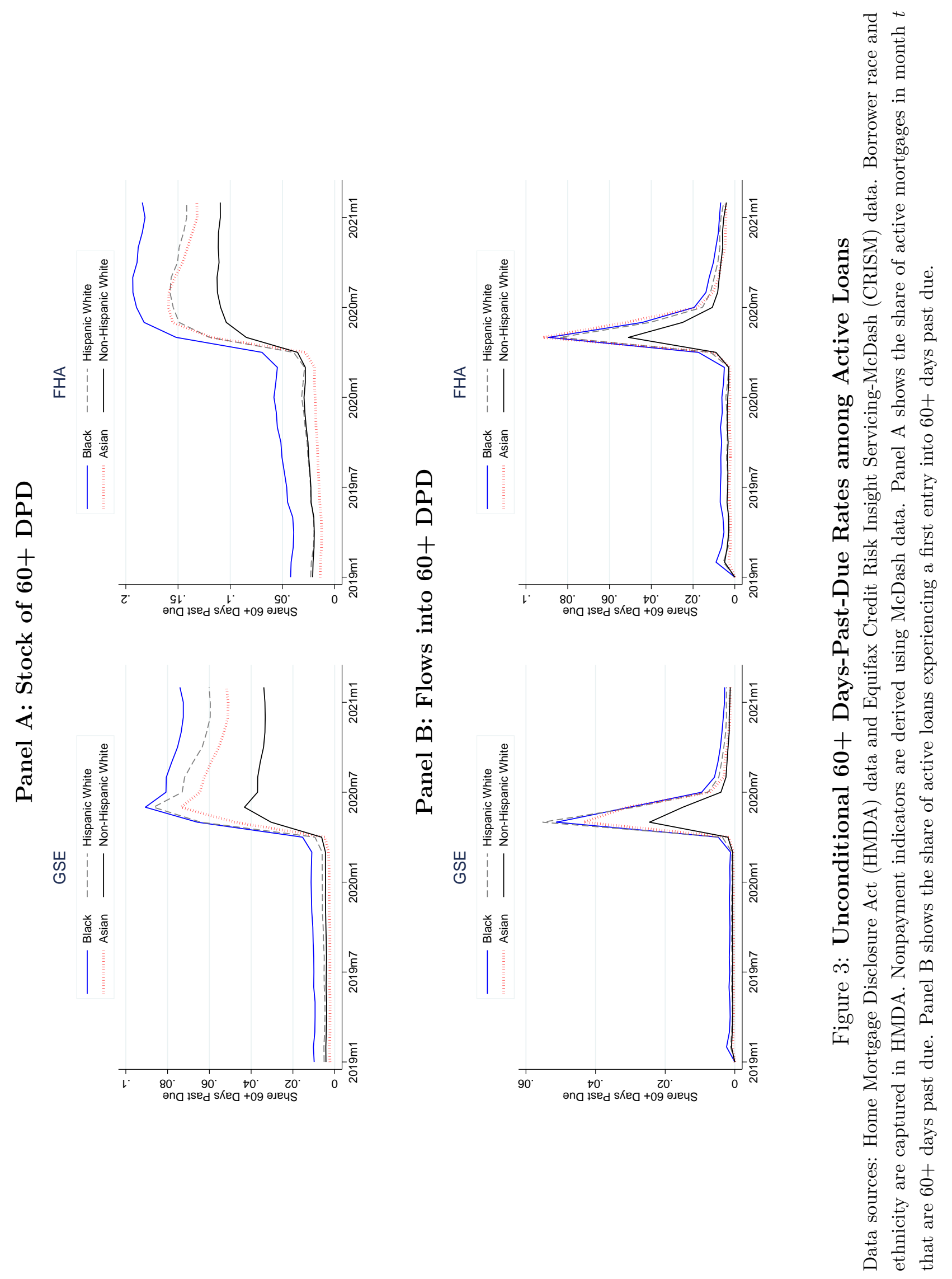

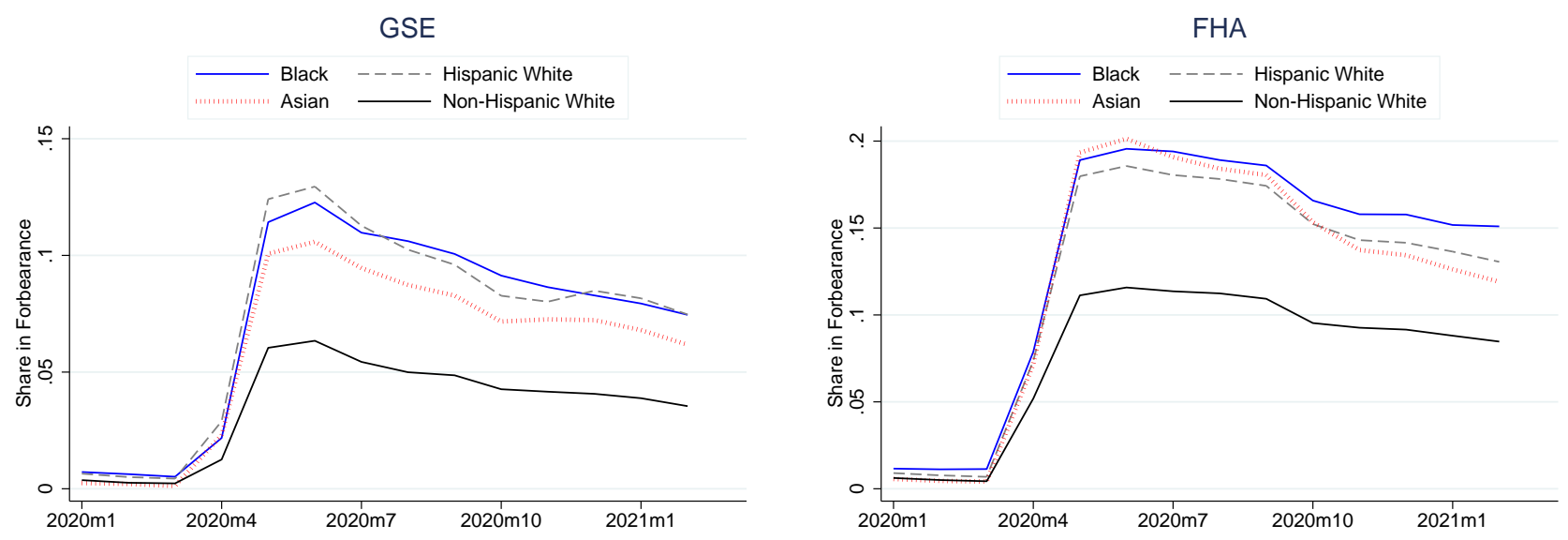

Figure 4: Unconditional Forbearance Rates among Active Loans

Data sources: Home Mortgage Disclosure Act (HMDA) data, Equifax Credit Risk Insight Servicing-McDash data, and Federal Reserve Bank of New York/Equifax Consumer Credit Panel (CCP) data. Borrower race and ethnicity are captured in HMDA. Forbearance indicators are derived using tradeline-level data from the CCP. 


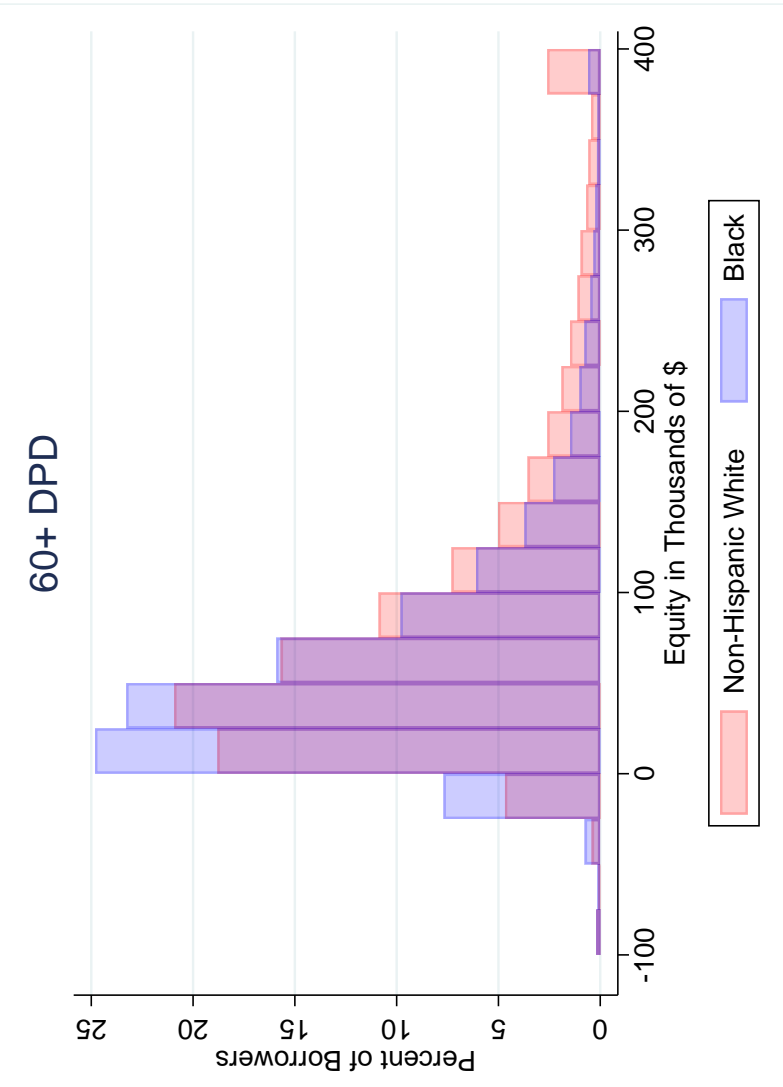

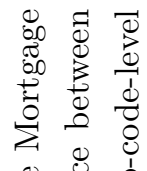

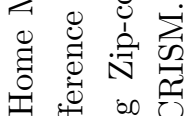

$\infty:$ :

赵

ग

च

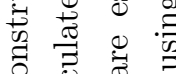

.

요

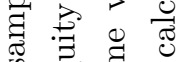

오용

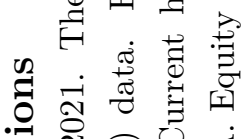

范盛

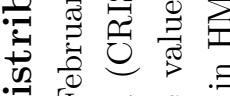

ค

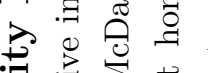

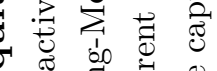

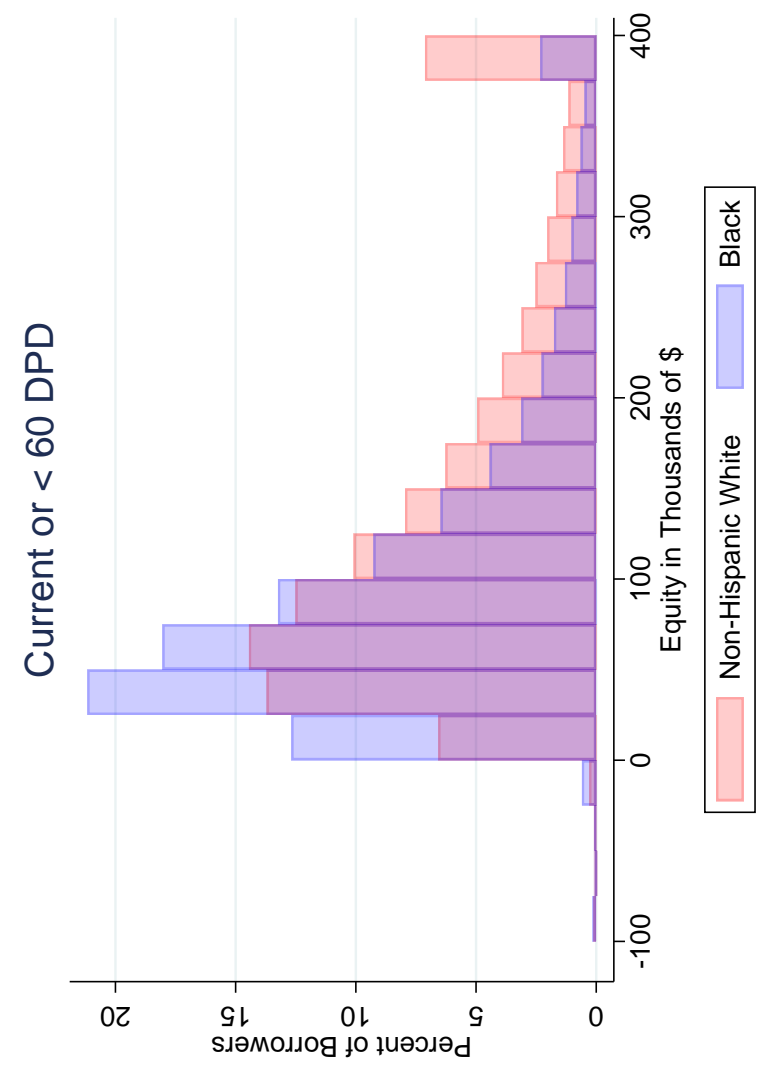

되 बै

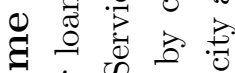

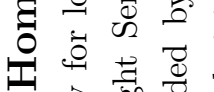

I 50.0

வ

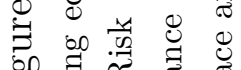

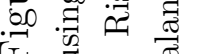

○: 苛

Чै

₹

究

余志选

渮

击

क क

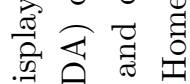

$\exists$

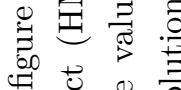

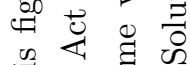

灵

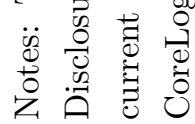




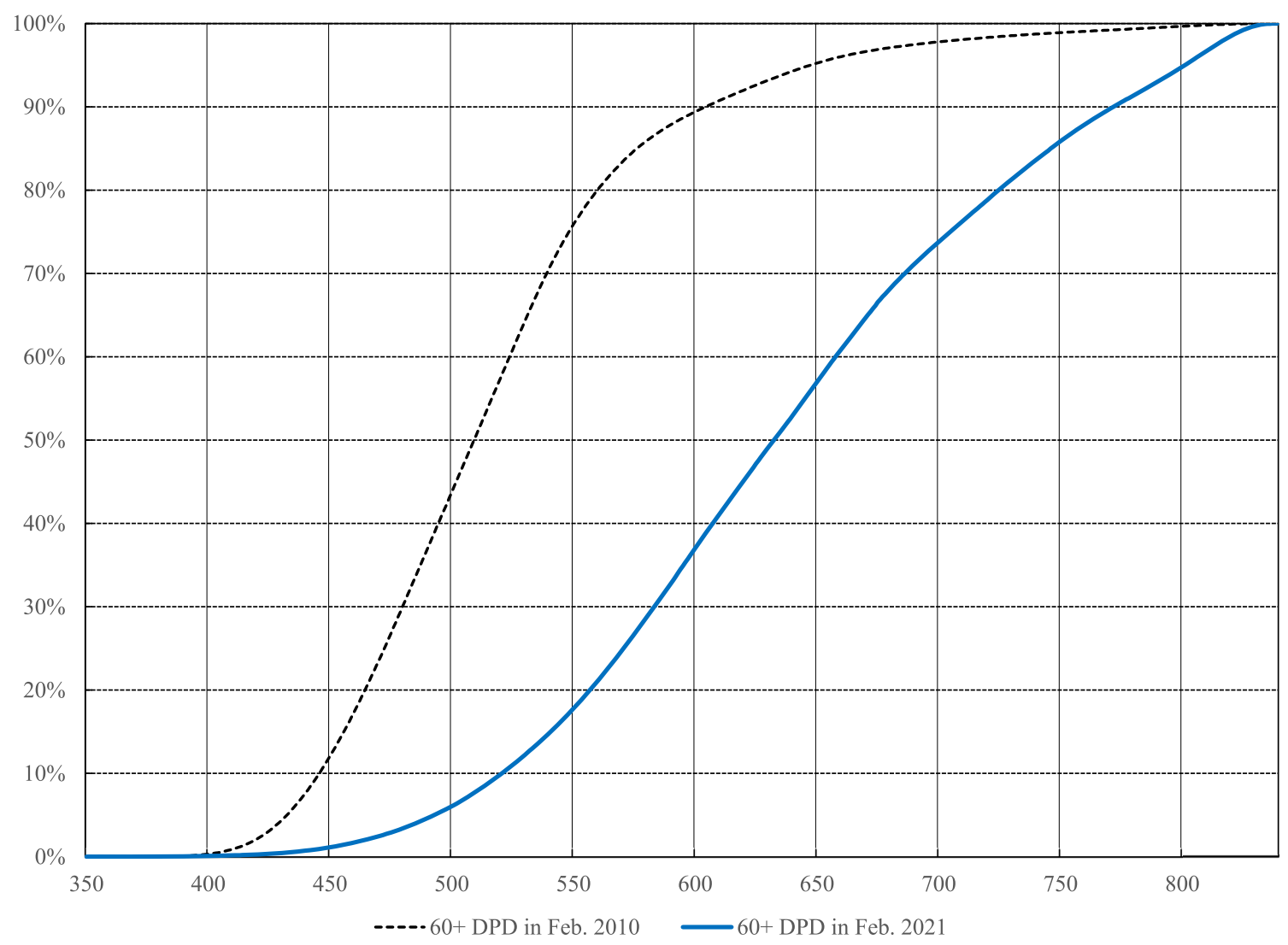

Figure 6: Cumulative Distribution of Scores for Past-Due Borrowers, 2010 vs. 2021

Notes: This figure displays the distribution of credit scores for active loans in February 2010 and February 2021 that were at least 60 days past due on payments. The sample is constructed using and Equifax Credit Risk Insight Servicing-McDash (CRISM) data. The credit score used in the plots is VantageScore 3.0. 

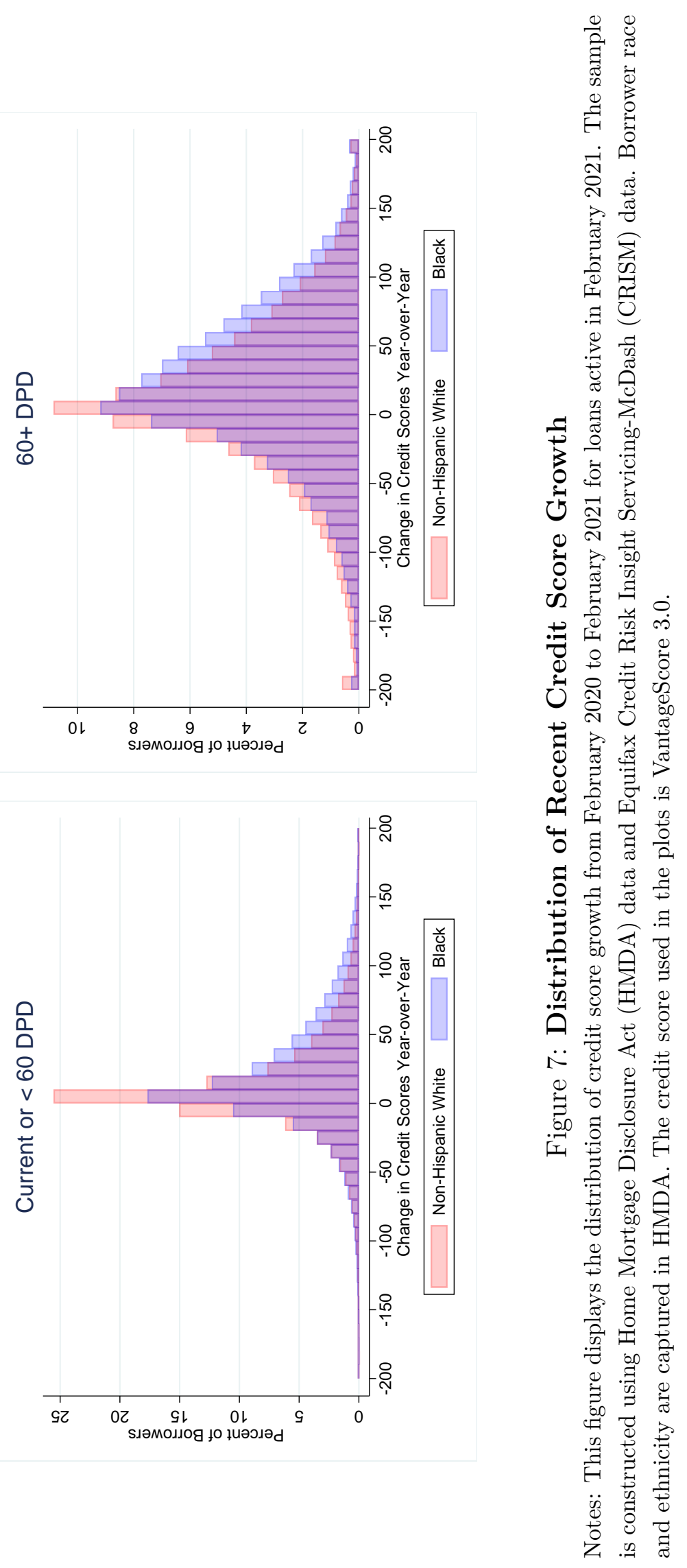
Table 1: Summary Statistics

\begin{tabular}{lccccc}
\hline & Total & White & Black & Hispanic & Asian \\
\hline Number of loans & $5,609,895$ & $3,860,622$ & 371,534 & 575,598 & 258,941 \\
Share of sample & $100 \%$ & $69 \%$ & $7 \%$ & $10 \%$ & $5 \%$ \\
Income at origination & $\$ 92,398$ & $\$ 94,537$ & $\$ 78,653$ & $\$ 76,915$ & $\$ 100,136$ \\
$\%$ FHA & $30 \%$ & $26 \%$ & $56 \%$ & $47 \%$ & $18 \%$ \\
\hline Mean for subsample active in January 2020 & & & \\
Updated CLTV & $62 \%$ & $61 \%$ & $68 \%$ & $65 \%$ & $58 \%$ \\
Updated credit score & 736 & 742 & 691 & 714 & 755 \\
Interest rate & $4.19 \%$ & $4.18 \%$ & $4.28 \%$ & $4.27 \%$ & $4.10 \%$ \\
\hline
\end{tabular}

Data sources: Home Mortgage Disclosure Act (HMDA) data and Equifax Credit Risk Insight ServicingMcDash (CRISM) data. Notes: Income is reported in 2021 dollars. Credit score is VantageScore 3.0. Updated variables are retrieved as of January 2020. 


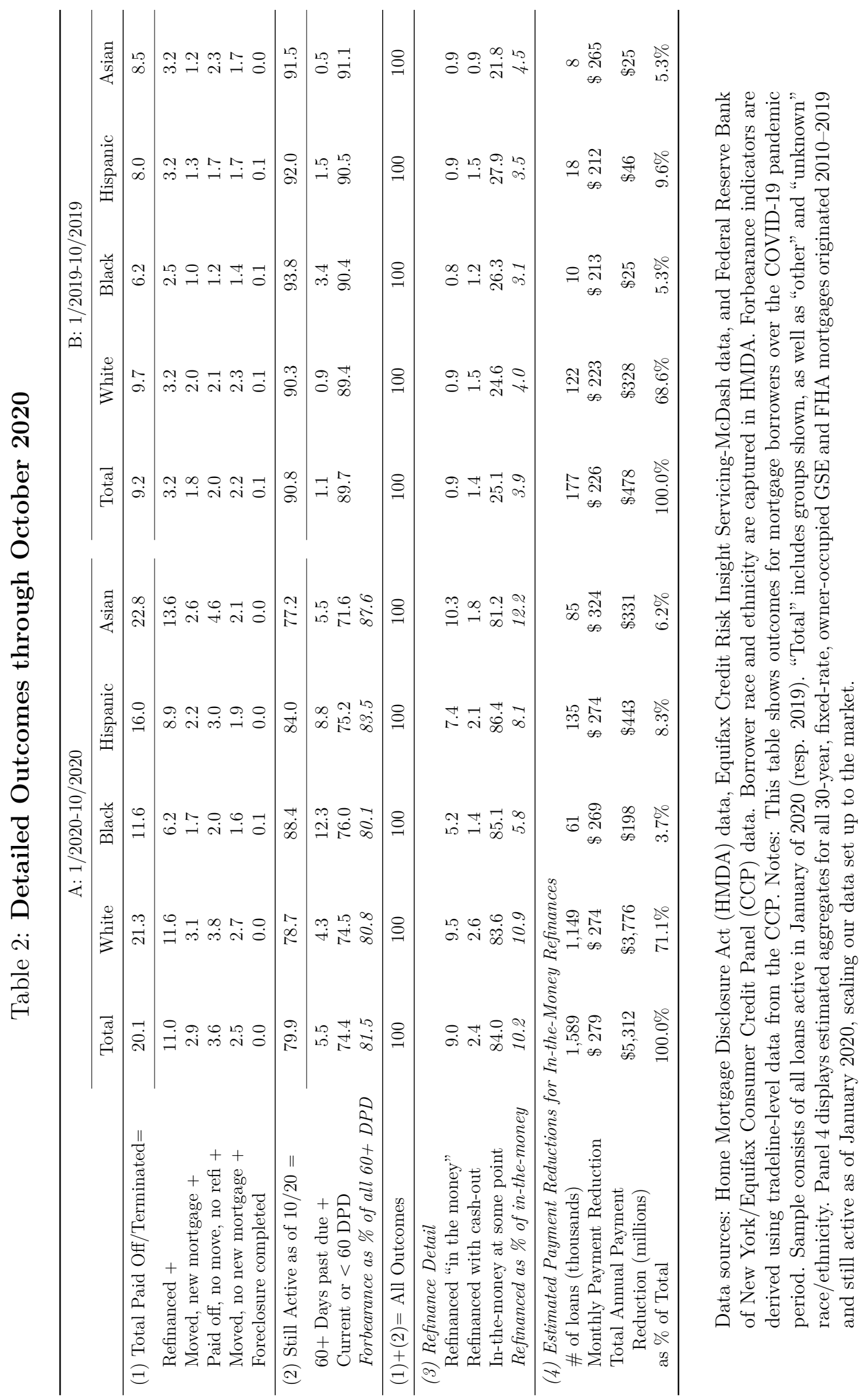


Table 3: Refinancing Disparities across Race/Ethnicity: Pre-Pandemic vs. Pandemic

\begin{tabular}{lcccc}
\hline & GSE \& FHA & GSE \& FHA & GSE & FHA \\
& $(1)$ & $(2)$ & $(3)$ & $(4)$ \\
\hline Pandemic & $3.777^{* * * *}$ & $1.614^{* * *}$ & $1.675^{* * *}$ & $1.223^{* * *}$ \\
& $(115.87)$ & $(47.80)$ & $(42.38)$ & $(15.97)$ \\
Black & $0.766^{* * *}$ & $0.911^{* * *}$ & $0.879^{* * *}$ & $0.764^{* * *}$ \\
& $(-7.11)$ & $(-4.28)$ & $(-4.24)$ & $(-15.10)$ \\
Hispanic & 0.957 & $0.884^{* * *}$ & $0.871^{* * *}$ & $0.724^{* * *}$ \\
& $(-0.83)$ & $(-7.26)$ & $(-6.88)$ & $(-17.51)$ \\
Asian & 1.050 & $0.843^{* * *}$ & $0.888^{* * *}$ & $0.757^{* * *}$ \\
& $(1.76)$ & $(-9.62)$ & $(-6.24)$ & $(-11.22)$ \\
Black x Pandemic & $0.651^{* * *}$ & $0.673^{* * *}$ & $0.723^{* * *}$ & $0.877^{* * *}$ \\
& $(-24.77)$ & $(-23.83)$ & $(-12.86)$ & $(-6.64)$ \\
Hispanic x Pandemic & $0.773^{* * * *}$ & $0.792^{* * *}$ & $0.852^{* * *}$ & $0.946^{*}$ \\
& $(-14.06)$ & $(-11.85)$ & $(-7.96)$ & $(-2.46)$ \\
Asian x Pandemic & $1.117^{* * *}$ & $1.139^{* * *}$ & $1.084^{* * * *}$ & $1.107^{* *}$ \\
Recently past due & $(5.92)$ & $(7.42)$ & $(4.50)$ & $(2.67)$ \\
& & $0.585^{* * *}$ & $0.669^{* * *}$ & $0.468^{* * *}$ \\
Recently past due x Pandemic & & $(-24.06)$ & $(-14.72)$ & $(-24.74)$ \\
& & $0.320^{* * *}$ & $0.297^{* * * *}$ & $0.410^{* * *}$ \\
Seasoned cure & & $(-47.93)$ & $(-38.28)$ & $(-27.91)$ \\
Seasoned cure x Pandemic & & $0.619^{* * *}$ & $0.691^{* * *}$ & $0.466^{* * *}$ \\
& & $(-24.30)$ & $(-14.49)$ & $(-26.82)$ \\
\hline Loan and Borrower Controls & $\mathrm{N}$ & $0.744^{* * *}$ & $0.774^{* * *}$ & $0.832^{* * *}$ \\
\# Observations & & $(-12.88)$ & $(-9.03)$ & $(-4.30)$ \\
\hline
\end{tabular}

Notes: This table displays estimated odds ratios from a logit model. The dependent variable is a dummy that is 1 if a mortgage prepays due to refinancing in year-month $t$ and 0 otherwise. The unit of observation is a loan-month. Column (1) does not include controls. Columns (2)-(4) include the following controls: cubic loan age, origination year-quarter dummies, state dummies, loan-to-value ratio at origination and estimated change in loan-to-value since origination, borrower income at origination, VantageScore 3.0 at origination and change since origination, full or low documentation at origination, whether the subject loan eligible for refinancing was a purchase or refinance loan, a condo dummy, a measure of the "moneyness" of refinancing following Deng, Quigley, and Van Order (2000), the difference between the rate the borrower received and the prevailing rate when the subject loan was originated, and dummy indicators that the loan was past due in months $t-3$ to $t-1$ ("recently past due") or current in those months but past due in months $t-11$ to $t-4$ ("seasoned cures"). Mortgages are followed from January 2019 through October 2020. "Pandemic" indicates months from April 2020 onward. Data sources: Home Mortgage Disclosure Act data, Equifax Credit Risk Insight Servicing-McDash (CRISM) data, house price indices from CoreLogic Solutions, and market interest rate data from Optimal Blue. $t$ statistics are reported in parentheses. Borrower race and ethnicity are captured in HMDA. Refi indicators are derived using data from CRISM. ${ }^{*} p<0.05,{ }^{* *} p<0.01$, ${ }^{* * *}$ $p<0.001$. 
Table 4: Nonpayment Disparities across Race/Ethnicity: Pre-Pandemic vs. Pandemic

\begin{tabular}{lcccc}
\hline & GSE \& FHA & GSE \& FHA & GSE & FHA \\
& $(1)$ & $(2)$ & $(3)$ & $(4)$ \\
\hline Pandemic & $8.481^{* * *}$ & $106.7^{* * *}$ & $381.6^{* * *}$ & $36.62^{* * *}$ \\
& $(110.35)$ & $(74.22)$ & $(79.16)$ & $(91.64)$ \\
Black & $3.055^{* * *}$ & $2.074^{* * *}$ & $1.917^{* * *}$ & $1.689^{* * *}$ \\
& $(40.13)$ & $(29.33)$ & $(18.03)$ & $(23.65)$ \\
Hispanic & $1.516^{* * *}$ & $1.103^{* * *}$ & 1.086 & $0.952^{*}$ \\
& $(10.85)$ & $(3.30)$ & $(1.90)$ & $(-2.06)$ \\
Asian & $0.594^{* * *}$ & $0.651^{* * *}$ & $0.674^{* * *}$ & $0.745^{* * *}$ \\
& $(-10.26)$ & $(-10.23)$ & $(-7.95)$ & $(-6.41)$ \\
Black x Pandemic & $0.789^{* * *}$ & $0.793^{* * *}$ & $0.917^{*}$ & $0.953^{*}$ \\
& $(-10.45)$ & $(-10.12)$ & $(-2.41)$ & $(-2.42)$ \\
Hispanic x Pandemic & $1.380^{* * *}$ & $1.293^{* * *}$ & $1.449^{* * *}$ & $1.431^{* * *}$ \\
& $(7.32)$ & $(5.47)$ & $(6.61)$ & $(10.06)$ \\
Asian x Pandemic & $2.695^{* * *}$ & $2.559^{* * *}$ & $2.423^{* * *}$ & $2.193^{* * *}$ \\
& $(24.04)$ & $(22.03)$ & $(19.42)$ & $(13.29)$ \\
\hline Loan and Borrower Controls & $\mathrm{N}$ & $\mathrm{Y}$ & $\mathrm{Y}$ & $\mathrm{Y}$ \\
\# Observations & $98,541,684$ & $94,135,334$ & $68,845,619$ & $25,289,715$ \\
\hline
\end{tabular}

Notes: This table displays estimated odds ratios from a logit model. The dependent variable is a dummy that is 1 if a mortgage becomes 60 days past due (2 payments behind) in year-month $t$ and 0 otherwise. The unit of observation is a loan-month. Column (1) does not include controls. Columns (2)-(4) include the following controls: cubic loan age, origination year-quarter dummies, state dummies, loan-to-value ratio at origination and estimated change in loan-to-value since origination, borrower income at origination, VantageScore 3.0 at origination and change since origination, full or low documentation at origination, whether the subject loan eligible for refinancing was a purchase or refinance loan, a condo dummy, a measure of the "moneyness" of refinancing following Deng, Quigley, and Van Order (2000), and the difference between the rate the borrower received and the prevailing rate when the subject loan was originated. Mortgages are followed from January 2019 through February 2021. "Pandemic" indicates months from April 2020 onward. Data sources: Home Mortgage Disclosure Act data, Equifax Credit Risk Insight Servicing-McDash (CRISM) data, house price indices from CoreLogic Solutions, and market interest rate data from Optimal Blue. Borrower race and ethnicity are captured in HMDA. Cure indicators are derived using McDash data. $t$ statistics are reported in parentheses. ${ }^{*} p<0.05,{ }^{* *} p<0.01,{ }^{* * *} p<0.001$. 
Table 5: Loan Outcomes of Borrowers Experiencing Pandemic-Related Distress

Panel A: Outcomes as of February 2021

\begin{tabular}{lccccc}
\hline & $\begin{array}{c}\text { Total } \\
(\%)\end{array}$ & $\begin{array}{c}\text { White } \\
(\%)\end{array}$ & $\begin{array}{c}\text { Black } \\
(\%)\end{array}$ & $\begin{array}{c}\text { Hispanic } \\
(\%)\end{array}$ & $\begin{array}{c}\text { Asian } \\
(\%)\end{array}$ \\
\hline Total active & 88.1 & 86.5 & 93.1 & 90.8 & 86.4 \\
\cline { 2 - 6 }$\quad$ 30+ days past due & 36.6 & 35.0 & 43.9 & 37.2 & 33.9 \\
$\quad$ Cured (current) & 51.5 & 51.5 & 49.2 & 53.6 & 52.5 \\
\hline Total Paid off & 11.9 & 13.5 & 6.8 & 9.2 & 13.6 \\
\hline Total & 100 & 100 & 100 & 100 & 100 \\
\hline Forbearance as \% of Past Due & 87.9 & 88.8 & 86.0 & 85.8 & 87.7 \\
\hline
\end{tabular}

\section{Panel B: Outcomes as of October 2020}

\begin{tabular}{lccccc}
\hline & $\begin{array}{c}\text { Total } \\
(\%)\end{array}$ & $\begin{array}{c}\text { White } \\
(\%)\end{array}$ & $\begin{array}{c}\text { Black } \\
(\%)\end{array}$ & $\begin{array}{c}\text { Hispanic } \\
(\%)\end{array}$ & $\begin{array}{c}\text { Asian } \\
(\%)\end{array}$ \\
\hline Total active & 94.8 & 93.9 & 97.0 & 96.2 & 94.4 \\
$\quad$ = 30+ days past due & 53.2 & 50.9 & 61.6 & 55.2 & 49.7 \\
$\quad$ + Cured (current) & 41.6 & 43.0 & 35.5 & 40.9 & 44.7 \\
\hline Total Paid off & 5.2 & 6.1 & 2.9 & 3.8 & 5.6 \\
\cline { 2 - 6 }$\quad$ Refinanced & 1.3 & 1.4 & 0.7 & 1.0 & 2.1 \\
$\quad$ + Moved, new mortgage & 1.3 & 1.5 & 0.8 & 1.0 & 1.4 \\
$\quad$ + Paid off, no move, no refi & 0.7 & 0.8 & 0.4 & 0.5 & 0.6 \\
$\quad$ + Moved, no new mortgage & 1.9 & 2.3 & 1.1 & 1.3 & 1.5 \\
\hline Total & 100 & 100 & 100 & 100 & 100 \\
\hline Forbearance as \% of Past Due & 88.8 & 89.2 & 88.2 & 86.7 & 88.7 \\
\hline
\end{tabular}

Data sources: Home Mortgage Disclosure Act (HMDA) data, Equifax Credit Risk Insight Servicing-McDash (CRISM) data, and Federal Reserve Bank of New York/Equifax Consumer Credit Panel (CCP). Notes: This table shows outcomes for mortgage borrowers who were current in February 2020 and who first became 60+ DPD in May or June 2020. Panel A displays outcomes calculated through February 2021, while Panel B displays outcomes calculated through October 2020 over the COVID-19 period (columns labed 2/2020$2 / 2021$ ) versus the same period a year earlier (column labeled 2019). "Total" includes groups shown, as well as "other" and "unknown" race/ethnicity. Borrower race and ethnicity are captured in HMDA. Loan outcomes are derived using CRISM data, with the exception of forbearance, which is identified using mortgage tradeline-level data from the CCP. 


\title{
Table 6: Recent House Price Growth and the Housing Equity Distribution
}

\author{
Panel A: Estimated House Price Growth, Feb. \\ 2020 to Feb. 2021 (\%)
}

\begin{tabular}{lcccccc}
\hline & & \multicolumn{5}{c}{ Percentile of Distribution } \\
\cline { 3 - 7 } & Mean & $\mathbf{5 t h}$ & $\mathbf{1 0 t h}$ & $\mathbf{2 5 t h}$ & $\mathbf{5 0 t h}$ & $\mathbf{7 5 t h}$ \\
\hline White & 10.3 & 3.5 & 5.3 & 7.7 & 10.0 & 12.8 \\
Black & 9.6 & 2.7 & 4.7 & 7.0 & 9.5 & 12.0 \\
Hispanic & 10.1 & 3.2 & 5.0 & 7.3 & 9.7 & 12.8 \\
Asian & 9.2 & 1.4 & 3.5 & 6.6 & 9.2 & 12.0 \\
Other & 10.5 & 3.7 & 5.3 & 7.8 & 10.1 & 13.1 \\
Unknown & 10.1 & 3.1 & 5.0 & 7.5 & 9.8 & 12.6 \\
\hline All Borrowers & 10.2 & 3.3 & 5.1 & 7.6 & 9.8 & 12.7 \\
\hline
\end{tabular}

Panel B: Estimated Housing Equity, Feb. 2021 (\%)

\begin{tabular}{lcccccc}
\hline & & \multicolumn{5}{c}{ Percentile of Distribution } \\
\cline { 3 - 7 } & Mean & 5th & 10th & 25th & 50th & 75th \\
\hline White & 46.7 & 18.4 & 23.9 & 34.1 & 46.1 & 58.9 \\
Black & 39.5 & 13.2 & 17.7 & 27.2 & 39.0 & 51.3 \\
Hispanic & 42.5 & 14.6 & 19.1 & 28.8 & 41.6 & 55.8 \\
Asian & 50.0 & 18.7 & 24.7 & 35.8 & 49.6 & 64.3 \\
Other & 46.3 & 17.3 & 22.4 & 33.0 & 45.7 & 59.5 \\
Unknown & 46.6 & 16.6 & 21.9 & 33.0 & 46.1 & 59.8 \\
\hline All Borrowers & 45.8 & 17.2 & 22.4 & 32.8 & 45.2 & 58.4 \\
\hline
\end{tabular}

Data sources: Home Mortgage Disclosure Act (HMDA) data, Equifax Credit Risk Insight Servicing-McDash (CRISM) data, and CoreLogic Solutions Home Price Indices. Notes: Panel A displays summary statistics for the distribution of area house price appreciation experienced from February 2020 to February 2021 by GSE and FHA loans that were active as of February 2021. Panel B displays similar statistics for the distribution of housing equity (difference between current home value and outstanding mortgage balance divided by current home value) for GSE and FHA loans that were active as of February 2021. Borrower race and ethnicity are captured in HMDA. Equity is derived using CRISM and CoreLogic data. 


\section{References}

Agarwal, Sumit, Souphala Chomsisengphet, Hua Kiefer, Leonard C. Kiefer, and Paolina C. Medina. 2020. "Inequality during the COVID-19 Pandemic: The Case of Savings from Mortgage Refinancing." Available at https://papers.ssrn.com/sol3/papers .cfm? abstract_id=3750133.

Agarwal, Sumit, John C. Driscoll, and David I. Laibson. 2013. "Optimal Mortgage Refinancing: A Closed-Form Solution." Journal of Money, Credit and Banking 45(4): 591-622.

An, Xudong, Larry Cordell, Liang Geng, and Keyoung Lee. 2021. "Inequality in the Time of COVID-19: Evidence from Mortgage Delinquency and Forbearance." Federal Reserve Bank of Philadelphia Working Paper (WP 21-09). Available at https ://www . philadelphiafed. org/-/media/frbp/assets/working-papers/2021/wp21-09.pdf.

Davydiuk, Tetiana, and Deeksha Gupta. 2020. "Income Inequality, Debt Burden and COVID-19." Available at http://dx.doi.org/10.2139/ssrn. 3641965.

Deng, Yongheng, John M. Quigley, and Robert Van Order. 2000. "Mortgage Terminations, Heterogeneity and the Exercise of Mortgage Options." Econometrica 68(2): 275-307.

Dettling, Lisa, and Lauren Lambie-Hanson. 2021. "Why Is the Default Rate So Low? How Economic Conditions and Public Policies Have Shaped Mortgage and Auto Delinquencies during the COVID-19 Pandemic." FEDS Notes. Available at https://www.federalreserve.gov/econres/notes/feds-notes/ why-is-the-default-rate-so-low-20210304.htm.

Durbin, Eric, Greta Li, David Low, and Judith Ricks. 2021. "Characteristics of Mortgage Borrowers during the COVID-19 Pandemic." CFPB Office of Research Special Issue Brief. Available at https://files.consumerfinance.gov/f/documents/ cfpb_characteristics-mortgage-borrowers-during-covid-19-pandemic_report_ 2021-05.pdf.

Fuster, Andreas, Aurel Hizmo, Lauren Lambie-Hanson, James Vickery, and Paul Willen. 2021. "How Resilient Is Mortgage Credit Supply? Evidence from the COVID-19 Pandemic." Federal Reserve Bank of Philadelphia Working Paper (WP 21-20). Available at https://www.philadelphiafed.org/-/media/frbp/assets/working-papers/ 2021/wp21-20.pdf. 
Gerardi, Kristopher, Kyle F. Herkenhoff, Lee E. Ohanian, and Paul S. Willen. 2018. "Can't Pay or Won't Pay? Unemployment, Negative Equity, and Strategic Default." The Review of Financial Studies 31(3): 1098-1131.

Gerardi, Kristopher, Paul Willen, and David Hao Zhang. 2020. "Mortgage Prepayment, Race, and Monetary Policy." Federal Reserve Bank of Atlanta Working Paper. Available at https://www.frbatlanta.org/research/publications/wp/2020/12/18/ 22-mortgage-prepayment-race-monetary-policy.

Lambie-Hanson, Lauren, and Carolina Reid. 2018. "Stuck in Subprime? Examining the Barriers to Refinancing Mortgage Debt." Housing Policy Debate 28(5): 770-796. Available at https://doi.org/10.1080/10511482.2018.1460384.

Van Dorn, Aaron, Rebecca E. Cooney, and Miriam L. Sabin. 2020. "COVID-19 Exacerbating Inequalities in the US." Lancet (London, England) 395(10232): 1243. 


\section{Appendix A: Technical Details}

The McDash data set identifies loans that have been paid off, but the data do not distinguish between types of payoff (refinance, selling the home, etc.). Following an approach similar to that of Lambie-Hanson and Reid (2018) and Gerardi, Willen, and Zhang (2020), we designate a borrower as having refinanced if they prepay their mortgage in month $t$ and take out a new mortgage that is closed between $t$ - 2 and $t+2$, and their address on their credit report indicates that they did not move between $t$ - 2 and $t+4$. A newly originated loan can take a couple of months to be reflected on a consumer's credit report, so we require a four-month window after payoff to allow these new accounts to appear. Given that the most recent CRISM data are for February 2021, this means we can distinguish refinances from other types of payoffs for loans paid off in October 2020 and earlier.

The data we use also do not include a flag for the loan being in forbearance, so we must derive it ourselves using the CCP data. Following Dettling and Lambie-Hanson (2021), we identify a borrower as in forbearance if they have one or more mortgage accounts with a nonzero balance but scheduled monthly payments set to zero, or if they have a mortgage account flagged in credit bureau account narrative codes as in forbearance, in deferral, approved for partial payments, or affected by a natural disaster. ${ }^{1}$ The natural disaster narrative code is commonly used by lenders to signify a COVID-19-related accommodation. Because natural disasters such as the western wildfires overlap with the pandemic, some borrowers in forbearance for non-pandemic reasons will be captured in this measure. We use the CCP data because these narrative codes and scheduled payment amounts needed for identifying forbearance are not part of CRISM. However, this means that for the subset of the analysis in which we look at the borrower's forbearance status, we must use the 5 percent subset of loans that are in the CCP.

Using race and ethnicity fields in HMDA, we categorize loans as being in six mutually exclusive and exhaustive categories, applying the following waterfall:

- Loans with the first borrower having an unknown race or ethnicity are classified as "unknown."

- Loans with one or more Black borrowers are categorized as "Black."

- Loans with one or more Asian borrowers are categorized as "Asian."

$\triangleright$ Loans with one or more white Hispanic borrowers are categorized as "Hispanic."

\footnotetext{
${ }^{1}$ Because we want to focus on loans in active forbearance accommodation, we deviate from Dettling and Lambie-Hanson (2021) in by excluding loans flagged as modified unless they have other indicators of being in active payment accommodation, such as a nonzero balance with scheduled payment set to zero.
} 
- Loans with one or more white non-Hispanic borrowers are categorized as "white."

- All remaining loans are categorized as "other." 


\section{Appendix B: Additional Results}
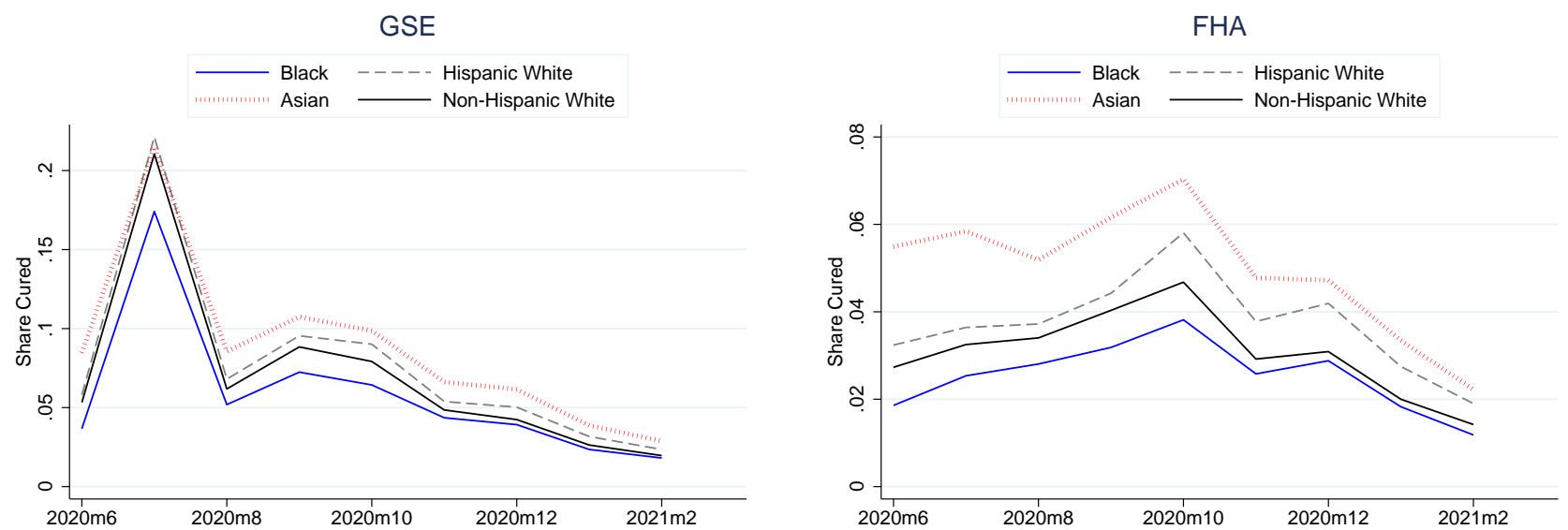

Figure B.1: Monthly Cure Rates for GSE and FHA Loans that Became 60+ Days Past Due in May or June 2020

Data sources: Home Mortgage Disclosure Act data and Equifax Credit Risk Insight Servicing-McDash (CRISM) data. Borrower race and ethnicity are captured in HMDA. Cure indicators are derived using data from CRISM. 


\section{Table B.1: Cure Rates across Race/Ethnicity: Pre-Pandemic vs. Pandemic}

\begin{tabular}{lcccc}
\hline & GSE \& FHA & GSE \& FHA & GSE & FHA \\
& $(1)$ & $(2)$ & $(3)$ & $(4)$ \\
\hline Pandemic & $0.779^{* * *}$ & $0.779^{* * *}$ & $1.253^{* * *}$ & $0.479^{* * *}$ \\
& $(-25.59)$ & $(-13.79)$ & $(10.07)$ & $(-35.23)$ \\
Black & $0.767^{* * *}$ & $0.855^{* * *}$ & $0.866^{* *}$ & $0.780^{* * *}$ \\
& $(-11.88)$ & $(-6.46)$ & $(-2.71)$ & $(-9.93)$ \\
Hispanic & $0.949^{*}$ & $1.053^{*}$ & 0.992 & 1.023 \\
& $(-2.26)$ & $(2.21)$ & $(-0.19)$ & $(0.88)$ \\
Asian & $1.132^{*}$ & 1.086 & 1.153 & 1.098 \\
& $(2.51)$ & $(1.48)$ & $(1.84)$ & $(1.33)$ \\
Black x Pandemic & 0.950 & 0.976 & 0.988 & 1.070 \\
& $(-1.74)$ & $(-0.76)$ & $(-0.21)$ & $(1.94)$ \\
Hispanic x Pandemic & 0.969 & 0.952 & 1.017 & 0.993 \\
& $(-1.17)$ & $(-1.95)$ & $(0.36)$ & $(-0.27)$ \\
Asian x Pandemic & 1.007 & 0.948 & 0.866 & 1.005 \\
& $(0.13)$ & $(-0.93)$ & $(-1.85)$ & $(0.07)$ \\
\hline Loan and Borrower Controls & $\mathrm{N}$ & $\mathrm{Y}$ & $\mathrm{Y}$ & $\mathrm{Y}$ \\
\# Observations & $2,150,891$ & $2,017,144$ & 919,697 & $1,097,447$ \\
\hline
\end{tabular}

Notes: This table displays estimated odds ratios from a logit model. The dependent variable is a dummy that is 1 if a mortgage becomes current or experiences a pay-off in year-month $t$ and 0 otherwise. To be included in the sample, the loan must have entered 60+ days past due in February 2019 or later. Only the first entry into nonpayment during this time is included. The unit of observation is a loan-month. Column (1) does not include controls. Columns (2)-(4) include the following controls: cubic loan age, origination year-quarter dummies, state dummies, loan-to-value ratio at origination and estimated change in loan-tovalue since origination, borrower income at origination, VantageScore 3.0 at origination and change since origination, full or low documentation at origination, whether the subject loan eligible for refinancing was a purchase or refinance loan, a condo dummy, a measure of the "moneyness" of refinancing following Deng, Quigley, and Van Order (2000), and the difference between the rate the borrower received and the prevailing rate when the subject loan was originated. Mortgages are followed from January 2019 through February 2021. "Pandemic" indicates months from April 2020 onward. Data sources: Home Mortgage Disclosure Act data, Equifax Credit Risk Insight Servicing-McDash (CRISM) data, house price indices from CoreLogic Solutions, and market interest rate data from Optimal Blue. Borrower race and ethnicity are captured in HMDA. Cure indicators are derived using data from CRISM. $t$ statistics are reported in parentheses. * $p<0.05,{ }^{* *} p<0.01,{ }^{* * *} p<0.001$. 